\section{Lithos}

Volume 96, Issues 3-4, July 2007, Pages 524-542

doi:10.1016/j.lithos.2006.12.001

(c) 2006 Elsevier B.V. All rights reserved
Archimer, archive institutionnelle de l'Ifremer http://www.ifremer.fr/docelec/

\title{
A possible link between gabbros bearing high-temperature iddingsite alteration and huge pegmatoid intrusions: The Society Islands, French Polynesia
}

\author{
Jean-Philippe Clément ${ }^{1}$, Martial Caroff ${ }^{1^{*}}$, Patrick Dudoignon ${ }^{2}$, Patrick Launeau ${ }^{3}$, Marcel \\ Bohn $^{4}$, Joseph Cotten ${ }^{1}$, Sylvain Blais ${ }^{5}$, Gérard Guille \\ ${ }^{1}$ UMR 6538 "Domaines Océaniques", IUEM, Université de Bretagne Occidentale, 6 avenue Victor Le Gorgeu, CS \\ 93837, 29238 BREST Cedex 3, France \\ ${ }^{2}$ UMR 6532 "HydrASA", Université de Poitiers, Ecole Supérieure d'Ingénieurs de Poitiers, 40 avenue du Recteur \\ Pineau, 86022 POITIERS Cedex, France \\ ${ }^{3}$ UMR 6112 "Planétologie et Géodynamique", UFR des Sciences et Techniques, Université de Nantes, 2 rue de \\ la Houssinière, 44072 NANTES, France \\ ${ }^{4}$ UMR 6538 "Domaines Océaniques", Ifremer - Centre de Brest, Département Géosciences Marines, BP 70, \\ 29280 PLOUZANE, France \\ ${ }^{5}$ UMR 6118 "Géosciences Rennes", Université de Rennes 1, 35042 RENNES, France \\ ${ }^{6}$ Groupe Télédétection et Risques Sismiques, DASE, CEA, BP 12, 91680 BRUYERES-LE-CHATEL, France \\ * Corresponding author: caroff@univ-brest.fr
}

\begin{abstract}
:
This paper reports new field observations and new petrological, textural and geochemical data on two gabbroic intrusions and one pegmatoid dyke from the French Polynesian islands Maupiti and Bora Bora, respectively. Olivine crystals from the Faataufi and Barque de Hiro gabbros (Maupiti) include High Temperature Iddingsite $(\mathrm{HTI})$, exhibiting three distinct morphological facies. Chemical and crystallographical data performed by electron microprobe, scanning microscope, X-ray diffractometry and Near InfraRed spectroscopy show that HTI results from modifications of olivine structure through intense hydroxylation and Fe-oxidation. The HTI-free $120 \mathrm{~m}$-wide Cloche de Hiro dyke (Bora Bora) exhibits a textural zonation from heterogranular/intergranular gabbro (peripheral part) to typical pegmatoid (inner area). We propose a textural tetrahedral classificatory diagram which can be used to clearly distinguish the textural characteristics of the pegmatoids from those of the other coarse-grained samples. Through comparison with a lava flow containing vesicle-rich segregation sheets, we suggest that the Cloche de Hiro dyke may correspond to a huge segregation structure derived from a Maupititype HTI-bearing gabbro through a vapor-differentiation process. Both intrusions might be considered as representative of two superposed levels in a vertically arranged magmatic complex. In this view, the Maupiti gabbroic bodies would represent the lower part of the postulated system. Under high oxygen fugacity, olivine crystals would have undergone important modifications of their structure, leading to $\mathrm{HTI}$. The huge Bora Bora pegmatoid dyke would be the upper part of the complex. After expulsion from the HTI-bearing gabbroic solidification zone by build-up of gas pressure, vesicle-rich residual melt would have gathered into a shallow level and crystallized there as a pegmatoid body.
\end{abstract}

Keywords: Gabbros; Olivine; Vapor-differentiation; Pegmatoid; French Polynesia; Society Islands 


\section{Introduction}

The iddingsite-like alteration of olivine at magmatic temperature has been observed for the first time by Edwards $(1938)$. Goff $(1977,1996)$ has yielded a detailed study of this alteration, named High Temperature Iddingsite ( $\mathrm{HTI})$ because of its close optical similarity with low-temperature postmagmatic iddingsite (LTI). HTI has been defined as an alteration facies of olivine formed under high oxygen fugacity (above the NNO buffer) and high temperature $\left(>1075^{\circ} \mathrm{C}\right)$. $\mathrm{HTI}$ affects olivine generally within diktytaxitic basalt flows or lakes containing vesiculated segregation structures (e.g., Boyers et al., 1996; Caroff et al., 1997, 2000; Wacaster and McConnell, 2002).

This specific alteration of olivine has never been described, to our knowledge, within coarse-grained intrusive bodies. The first aim of the paper is to point out the specificities of HTI in such rocks. The studied rocks are gabbros sampled in two intrusions (Faataufi and Barque de Hiro) from Maupiti island (Society archipelago, French Polynesia). They have been collected in October 1999 during a field mission organized by the French CEA and BRGM (Commissariat à l'Energie Atomique and Bureau de Recherche Géologique et Minière). The Faataufi intrusion contains a pegmatoid enclave. HTI from Maupiti displays three contrasted morphological facies. From a set of optical, chemical and cristallographic data, we propose here a preliminary mineralogical model of HTI that clearly differs from the published ones (Goff, 1977, 1996).

The second purpose of this article is to study a giant pegmatoid segregation structure from Bora Bora (Society archipelago): the 120 m-thick Cloche de Hiro dyke. This intrusion gives us the opportunity to distinguish in a new classificatory diagram the textural features specific to pegmatoids from those characterizing the other coarse-grained rocks.

Lastly, the possibility of a genetic link between HTI-bearing gabbros and huge pegmatoid bodies is discussed by making a comparison between the Society intrusions and a lava flow from Cantal (France) containing both $\mathrm{HTI}$ and pegmatoid segregation sheets (Caroff et al., 1997).

\section{High Temperature Iddingsite ( $\mathrm{HTI})$ and associated segregation}

\section{structures: a review}

\subsection{Morphological and chemical characteristics of HTI}

Goff (1996) has described thin red-orange HTI alteration rings affecting the periphery of olivine phenocrysts $\left(\mathrm{Fo}_{88-80}\right)$ within continental $3-10$ m-thick basalt flows. Except in glassy samples, $\mathrm{HTI}$ is systematically rimmed by ferrous $\left(\mathrm{Fo}_{65-28}\right)$ fresh overgrowth which crystallizes following the cristallographic axes of the fresh core. Caroff et al. (1997, 1999, 2000) have studied HTI within continental and oceanic 2-20 m-thick basalt flows. They have shown that the thermal retraction cracks of the olivine phenocrysts remain unaffected by this alteration. Caroff et al. (2000) have noted that cores of the largest (and so the earliest) microcrysts are also altered, when the host rock is not too fine textured.

Caroff et al. (2000) yielded in situ chemical analyses of HTI, performed by electron microprobe on phenocrysts from lava flows of Cantal (France). In the thin HTI rings, the olivine cationic proportions appear to be preserved. However, the altered zones are systematically more ferrous $\left(\mathrm{Fo}_{62}\right)$ than the corresponding fresh cores $\left(\mathrm{Fo}_{82-84}\right)$. In addition, they are characterized by a deficit in the analytical sum (ca. 7\%), interpreted as the result of water incorporation during HTI formation.

Following the X-ray diffraction results published by Goff (1977), HTI would be made up of a cryptocrystalline aggregate of orthopyroxene, cristoballite, amorphous silica, maghemite $\left(\gamma-\mathrm{Fe}_{2} \mathrm{O}_{3}\right)$ and hematite $\left(\alpha-\mathrm{Fe}_{2} \mathrm{O}_{3}\right)$, a mineral association rather consistent with the results of olivine oxidation experiments at high temperature (Koltermann, 1962; Goode, 1974; Gualtieri et al., 2003). This composition obviously differs from that of the low-temperature iddingsite (LTI), which is an intimate mixture of hydrous iron and magnesium silicates (goethite, montmorillonite, illite, chlorite: Gay and Le Maître, 1961, Fawcett, 1965, Lemaitre et al., 1966, Schandl et al., 1990, Schenato et al., 2003). Contrary to HTI, LTI postdates the thermal retraction cracks. The distinction between the two kinds of alteration is sometimes uneasy, especially in glassy samples, where the fresh olivine overgrowth is lacking, and also when LTI overprints HTI.

According to Goff (1996) and Furgal and McMillan (2001), HTI is the product of olivine alteration at temperatures higher than $1075^{\circ} \mathrm{C}$. The alteration process would occur before emplacement of the lava (either in the chimney or in the magma chamber), as a result of a temporary increase of oxygen fugacity and $\mathrm{H}_{2} \mathrm{O}$ content. Goff (1996) proposed that the volatile oversaturation in magma might result from infiltration of meteoric water at a late stage in the evolution of the magma, just before eruption.

The observation by Caroff et al. (2000) in lava flows from Cantal of large high-temperature iddingsitized microcrysts suggests that the highly oxidizing conditions may continue after eruption and 
emplacement. The authors proposed that the water at the origin of temporary high $\mathrm{f}_{\mathrm{O} 2}$ conditions might have a magmatic origin. If a mafic magma reaches quickly the surface without degassing, the persistance of large water oversaturation, capable of inducing magmatic oxidizing conditions as a result of $\mathrm{H}_{2} \mathrm{O}$ dissociation, is possible after eruption, for a while, provided that bubbles have not nuclated prior to lava emplacement (Caroff et al., 2000). In any case, the HTI formation stops when oxygen fugacity drops below the FMQ (Fayalite-Magnetite-Quartz) buffer, as the result of water boiling. Thin overgrowths then form.

\subsection{Segregation structures in HTI-bearing lavas}

Vesicle-rich segregation structures (cylinders, veins, sheets) involving residual liquid formed in situ during cooling of lava flows are generally interpreted as the product of a vapor-driven differentiation mechanism (Goff, 1996; Rogan et al., 1996; Caroff et al., 2000; Costa et al., 2006; Waichel et al., 2006). Crystallization of anhydrous minerals in the margins of the flows causes massive exsolution of the dissolved gas into bubbles (a process commonly referred to as second boiling). Then, just above the lower solidification front, plumes can form by gas-filter pressing (i.e. expulsion of vesicle-rich residual melt out of the region of crystallization as a result of the buildup of gas pressure; Sisson and Bacon, 1999). The plumes transform into vertical cylinders and/or horizontal sheets after the flow solidification. Even if segregation structures do not occur only in HTI-bearing lava flows (e.g. Philpotts et al., 1996, 1998; Self et al., 1996, 1997; Thordarson and Self, 1998; Merle et al., 2005; Sigmarsson et al., 2005), the association of both segregations and HTI is very common (Caroff et al., 2000). In addition, HTI-bearing lavas invariably have porous diktytaxitic textures that attest to the expansion of the intimate mixture of crystals and residual melt by $\mathrm{H}_{2} \mathrm{O}$ vapor during final stages of crystallization (Goff, 1996).

Pegmatoid texture has been described in the vesicle-rich segregation sheets present in the thickest HTI-bearing lava flows (Puffer and Horter, 1993; Caroff et al., 1997). They occur in the upper half of the flows thicker than approximately $15 \mathrm{~m}$, up to a few meters beneath the top. Their minerals show low integrity and abnormal crystallization features: elongation of olivine, clinopyroxene, or plagioclase and wide skeletal crystals of Fe-Ti oxides and olivine. Pegmatoids are systematically chemically more evolved than the host-lavas. Each pegmatoid sheet consists of either (1) a single thick pegmatoid layer containing cryptocrystalline patches or (2) an alternation of such layers with thinner leucocratic and microlitic layers (Caroff et al., 2000). In other vesicle-rich segregation structures, especially in vesicle cylinders, all the intermediates may exist between a completely glassy texture and a pegmatoid one: it is the "hyalodoleritic texture" of Lacroix (1904), redefined as "glassy texture with large acicular crystals" (GAC) by Caroff et al. (2000). 


\section{3. $\mathrm{HTI}$ in the gabbroic intrusions of Maupiti}

\subsection{Field data, petrology and geochemistry}

Maupiti island is located at the northwestern end of the Society archipelago, French Polynesia, $460 \mathrm{~km}$ away from the active area of the Society hot spot (Mehetia island, Fig. 1a). This volcano is the oldest emerged one in the chain (subaerial activity from 4.51 to 4.21 Ma: Guillou et al., 1998; Blais et al., 2002). The aerial part of the edifice is mainly made up of olivine-tholeiite basalt and hawaiite flows (Fig. 1a). Two coarse-grained gabbroic bodies, the Faataufi and Barque de Hiro intrusions, crop out near the northwestern coast (Fig. 1a,b).

The Faataufi intrusion, cleared by erosion, makes a E-W crest, the flanks of which are covered by screes of gabbro (Fig. 1b). In place coarse-grained rocks crop out at the summit on an $160 \mathrm{~m} \times 45 \mathrm{~m}$ surface area. The retraction prisms show that the original morphology of the Faataufi intrusion was more complex than a simple E-W-trending thick dyke. The gabbro (samples MUG-1 to MUG-6A, and MUG-7) exhibits a fairly homogeneous facies along the crest. It is an equigranular coarse-grained rock (grain size from 0.5 to $1 \mathrm{~mm}$ ) composed of 43 vol.\% plagioclase $\left(\mathrm{An}_{50-70}\right), 24$ vol.\% clinopyroxene (diopside $80 \leq \mathrm{Mg} \#=100 \mathrm{Mg} /[\mathrm{Mg}+\mathrm{Fe}] \leq 84)$, and 29 vol.\% HTI-bearing olivine $\left(\mathrm{Fo}_{62-68}\right)$ (Fig. 2a). Minor phases are interstitial alkali feldspars, apatite, Fe-Ti oxides (3 vol.\%), and phlogopite $\left(\mathrm{TiO}_{2} \approx 8\right.$ wt.\%). Close to the western end of the crest, a pegmatoid enclave (c. $80 \mathrm{~cm}$ in diameter, sample MUG-6B: Fig. 2b) can be observed within the Faataufi gabbro. It has the same mineralogy as the host gabbro but the minerals are different in composition: more sodic plagioclase $\left(A n_{42-58}\right)$, less magnesian clinopyroxene (diopside $57 \leq \mathrm{Mg} \# \leq 79$ ) and olivine $\left(\mathrm{Fo}_{32-69}\right)$. Euhedral Fe-Ti oxides are very abundant. Olivines contain $\mathrm{HTI}$ cores, few in number, similar to those observed in the gabbro. Although the association $\mathrm{HTI} /$ pegmatoid is usual in lava flows, the presence of HTI within pegmatoids is exceptional (Caroff et al., 2000).

The Barque de Hiro intrusion crops out in a small valley at an altitude ranging from 45 to $110 \mathrm{~m}$ (Fig. 1b). It emplaced as a $60 \mathrm{~m}$-thick and $300 \mathrm{~m}$-long dyke. The rock exhibits 5 to $20 \mathrm{~cm}$-spaced vertical flowing planes, from $\mathrm{N} 30^{\circ} \mathrm{E}$ to $\mathrm{N} 48^{\circ} \mathrm{E}$ in direction. A vertical contact between the Barque de Hiro intrusion and basalts is observable at the eastern edge of the outcropping area (Fig. 1b). Such as the Faataufi intrusion, the Barque de Hiro dyke (samples MUG-8 to MUG-14: Fig. 1b) is an equigranular gabbro. Grain size is fairly similar in both intrusions, with the exception of MUG-14, a more finegrained sample, porphyritic in pyroxenes. The modal proportions of the Barque de Hiro gabbro change along the sampling profile from west to east: plagioclases $\left(\mathrm{An}_{40-70}\right)$ vary from 60 vol.\% to 38 vol.\%, olivine from 14 vol.\% to 28 vol.\%, and clinopyroxene (diopside $72 \leq \mathrm{Mg} \# \leq 89$ ) from 20 vol.\% to 29 vol.\%. Only the olivines of the westerner samples (MUG-8 and -10) are devoid of HTI. Minor phases are interstitial alkali feldspar $\left(\mathrm{Or}_{10-70}\right)$, apatite, Fe-Ti oxides (2 vol.\% - 4 vol.\%), and phlogopite or biotite $\left(2<\mathrm{TiO}_{2}<9\right.$ wt.\%). Samples MUG-8 and -10 contain abundant (3 vol.\%) secondary zeolites and chlorites in vacuoles. The variation of the mineral proportions within the Barque de Hiro gabbro along the sampling profile is accompanied by an evolution of the HTI morphology (see further down in the text).

Fourteen samples representative of the coarse-grained bulk rocks of Maupiti have been analyzed for major and trace elements by ICP-AES in Brest (Table 1). The analytical method is described in Cotten et al. (1995); relative standard deviations are $<2$ wt.\% for major elements and $<5$ wt. $\%$ for trace elements. In the total alkali-silica (TAS) classification diagram of Le Bas et al. (1986), all the gabbroic and pegmatoid samples from Maupiti plot within the basaltic field (Fig. 3). $\mathrm{Fe}_{2} \mathrm{O}_{3}{ }^{*}$ and $\mathrm{MgO}$ compositions in gabbroic samples are comparable in both intrusions. MgO contents (from 9.65 to 13.50 wt.\%) are typical of primitive magmas (Table 1). The Faataufi and Barque de Hiro intrusions can be distinguished from one another by their $\mathrm{P}_{2} \mathrm{O}_{5}$ and $\mathrm{TiO}_{2}$ contents, higher in the Barque de Hiro samples (Table 1). In addition, the Barque de Hiro gabbros are the only rocks in Maupiti having normative nepheline (ne $\mathrm{N}_{\mathrm{N}} \leq 0.93 \mathrm{wt} \%$ : Table 1 ). The Faataufi pegmatoid sample (MUG-6B) is clearly distinct from the host gabbro: close to the hawaiitic field, it is enriched in alkali elements (Fig. 3$), \mathrm{P}_{2} \mathrm{O}_{5}$ and $\mathrm{TiO}_{2}$, and depleted in $\mathrm{MgO}$.

The Faataufi gabbroic samples have quite homogeneous incompatible trace elements contents, whereas the pegmatoid MUG-6B is obviously more evolved (Table 1). The Barque de Hiro coarse-grained rocks are systematically richer than the Faataufi ones in highly incompatible elements. Note that there is no chemical difference between the samples having fresh olivines and most of the HTI-bearing rocks. However, samples MUG-13 and -14 (collected close to the eastern contact with the basalts: Fig. 1b) are characterized by notable enrichments in Th, La, and Nb (Table 1). In the chondrite-normalized REE diagram of Fig. $4 \mathrm{a}$ are shown the patterns of samples representative of the chemical diversity in both intrusions. The two patterns intersect at the level of $\mathrm{Er}$, the Barque de Hiro samples exhibiting $L a_{N} / Y b_{N}$ values higher than the Faataufi ones. The pegmatoid MUG-6B presents, with respect to the Faataufi gabbroic samples, a pattern almost parallel but shifted toward the high REE contents. 


\subsection{Morphological and structural characteristics of Maupiti HTI}

In the Faataufi intrusion, HTI occurs as translucent oval red-brown cores (type I, Fig. 5a and c) in a few of olivine crystals (13 vol.\% of olivine is altered). Several HTI cores can be observed in a single olivine crystal (Fig. 5a). Typical HTI cores of type I include a rust-colored central part (I-A1), rimmed with a dark-red more opaque external part (I-A2, Fig. 5a). HTI cores are surrounded by very thick overgrowth rims (I-R) in optical continuity.

In the Barque de Hiro dyke, the HTI morphology and the volumic fraction of altered olivine change progressively with altitude from west to east (Fig. 1b). Four facies can be observed from $45 \mathrm{~m}$ to $110 \mathrm{~m}$ in altitude.

From 45 m to 70 m (MUG-8 and -10), olivine is devoid of HTI and exhibits locally only low temperature iddingsite ( $\mathrm{LTI})$.

At an altitude of 70 m (MUG-11), olivine crystals contain HTI cores of type I. 25 vol.\% of olivines are altered.

In the sample MUG-12 (90 $\mathrm{m}$ in altitude), 36 vol.\% olivines are affected by HTI (Fig. 1c). In the smallest olivine crystals (up to $1 \mathrm{~mm}$ ), HTI has a type I morphology (Fig. 5a). But in the largest crystals, HTI occurs as thick rings (type II, Fig. 5b) that separate fresh olivine cores (II-C) from thick overgrowth areas (II-R). These HTI rings are made up of two parts: a rust-colored translucent inner area (II-A1) and a dark-red external ring (II-A2).

Close to the eastern contact (porphyritic finer-grained sample MUG-14, $110 \mathrm{~m}$ in altitude; Fig. 1b), all the olivine crystals include HTI (43 vol.\% of olivine is altered). Its morphology (type III: Fig. $5 d$ ) is similar to that described by Goff (1996) and Caroff et al. (1997, 2000): red-brown thin rings (III-A) that isolate large fresh olivine cores (III-C) from thin fresh overgrowth rims (III-R). Central and peripheral fresh olivine areas crystallized following similar crystallographical axes. The smallest olivine crystals (lesser than $100 \mu \mathrm{m}$ in diameter) are devoid of fresh core.

In order to detect the existence of a possible cryptocrystalline aggregate in $\mathrm{HTI}$ and to determine its mineralogical composition, we have applied X-ray diffractometry on (non-oriented) magnetically separated olivines from two rocks sampled in the Barque de Hiro intrusion: MUG-12 and -14. Diffraction spectra have been obtained by a Philips PW1729 diffractometer (Cu K $\alpha$ radiation, 40 kV, $40 \mathrm{~mA}$; University of Poitiers, France). MUG-12 contains $500 \mu \mathrm{m}$ - to $1 \mathrm{~mm}$-large olivine crystals including $\mathrm{HTI}$ of type I and II and MUG-14 contains $160 \mu \mathrm{m}$ - to $315 \mu \mathrm{m}$-large olivine crystals including HTI of type III. Fe-oxides and olivine are the only minerals which have been clearly identified in our separations. The three morphological types of HTI contain significant amounts of ferric oxides (maghemite and/or magnetite), revealed by the $1.60-1.62 \AA$ XRD reflections. No ray characteristic of other cryptocrystalline minerals has been detected.

The back scattered electron image of Fig. 5c, performed using a scanning electron microscope (SEM) on sample MUG-2 (type I HTI, Faataufi intrusion), reveals an important density contrast between the central part of the HTI core (I-A1) and the thick fresh overgrowth rim (I-R). Indeed, the central part of the HTI core appears to be much clearer (and then denser) than the overgrowth rim (grey on Fig. 5c). The "limpidity" of the altered areas in the SEM image, not consistent with the presence of a cryptocrystalline aggregate, seems to confirm that HTI of type I remains olivine in a structural point of view. HTI cores are affected by a specific network of parallel cracks. The dark red external border of the core (I-A2) presents a strong porosity, expressed as micro-voids (blacks spots in the Fig. $5 c$ inset). In addition, the inner part of this border exhibits a dense network of radial microcracks, whereas its outer part is bounded by concentric microcracks (Fig. $5 \mathrm{c}$ inset).

\subsection{HTI chemistry}

The major element compositions of olivines and HTI from the Maupiti intrusions are presented in Table 2, together with the corresponding structural formulae (cations per formula unit of olivine). Ninety in situ analyses have been performed but only twenty-two compositions (the most representative of the chemical diversity of $\mathrm{HTI}$ ) are shown. $\mathrm{HTI}$ shows systematically a deficit in electron microprobe / SEM analytical sums. This lack ranges from c. 4 to 8 wt.\% in the external parts of the cores and thick rings (I- and II-A2: MUG-2 and -12) and in the thin rings (III-A: MUG-14). The deficit is much higher (from c. 12 to $25 \mathrm{wt} \%$ ) in the rust-colored inner parts of the cores and thick rings (I- and II-A1). This analytical deficit has been confirmed by measures of Loss On Ignition (LOI) on olivine crystals separated from MUG-12, including HTI cores: LOI = $4.3 \mathrm{wt} \%$. This value is probably underestimated because: 1) the analyzed crystals include anhydrous fresh olivine, and 2) no correction of the mass gain resulting from atmospheric $\mathrm{Fe}^{2+}$ oxidization during the heating process (at $1050^{\circ} \mathrm{C}$ ) has been made. Some approximate measurements, performed by electron microprobe, have 
shown that volatile $(\mathrm{F}, \mathrm{Cl}, \mathrm{B}, \ldots)$ and trace element $(\mathrm{Sr}, \mathrm{Rb}$, light rare earth elements...) contents are not sufficiently high to account for the observed analytical deficit.

The chemical composition can be used to recognized two distinct chemical groups of $\mathrm{HTI}$, whatever is the sample or the intrusion considered:

(1) The first chemical group is formed by the rust-colored parts of the cores and thick rings (I- and II-A1). These areas, corresponding to the clearest (densest) zones of the SEM images, have a fayalitic composition ( $3<\mathrm{Fo}<37$, Table 2). They are highly enriched in $\mathrm{Al}$ and $\mathrm{Ca}$ (up to $1.9 \mathrm{wt} . \%$ $\mathrm{Al}_{2} \mathrm{O}_{3}$ and $1 \mathrm{wt} . \% \mathrm{CaO}$ ) with respect to a standard fresh olivine (Table 2), and are systematically characterized by $\mathrm{Si}<1$, and $\mathrm{Mg}+\mathrm{Fe} \geq 2$ (cations per formula unit of olivine).

(2) The second group includes the dark-red porous external parts of the HTI cores and thick rings (I- and II-A2), and the HTI thin rings (III-A). They are characterized by magnesian compositions $(42<$ Fo $<62$, Table 2). These values are broadly comparable to those obtained within the fresh overgrowth rims, whatever is their thickness (I- and III-R, Table 2). The dark-red "magnesian" $\mathrm{HTI}$ is moderately enriched in $\mathrm{Al}$ and $\mathrm{Ca}$ (up to 1.2 wt. $\% \mathrm{Al}_{2} \mathrm{O}_{3}$ and $0.8 \mathrm{wt} . \% \mathrm{CaO}$ ) and is characterized by $\mathrm{Si}>1$ and $\mathrm{Mg}$ $+\mathrm{Fe}<2$ (cations per formula unit of olivine). We can note that HTI of type III from Cantal (Neirebrousse, Le Battut and Bouzentès lava flows: Caroff et al. 2000) have the chemical characteristics of this second group.

A c. $750 \mu \mathrm{m}$-long SEM chemical profile across a HTI core of type I (MUG-2, Faataufi) is shown in Fig. 6 (see Fig. $5 \mathrm{c}$ for the localisation of the profile). In addition, sixteen selected chemical compositions are presented in Table 2. Whatever is the considered parameter, the porous external part (I-A2) exibits strongly varying compositions. It seems to be a transition zone between two areas having fairly constant chemical composition: the dense fayalitic $\left(\mathrm{FO}_{5}\right)$ central part of the core $(\mathrm{I}-\mathrm{A} 1)$ and the fresh magnesian $\left(\mathrm{Fo}_{65}\right)$ olivine thick overgrowth rim $(\mathrm{I}-\mathrm{R})$.

\section{Pegmatoids in Bora Bora: the Cloche de Hiro dyke}

Bora Bora island is located $40 \mathrm{~km}$ south-east to Maupiti (Fig. 1a). The subaerial activity of this very eroded volcano is more recent (from 3.45 to $3.10 \mathrm{Ma}$ : Blais et al., 2000). The majority of the emerged part of the edifice is made up of alkali basalt and scarce hawaiite thin flows (Fig. 1c; Blais et al., 2000). The partly immersed sub-circular caldera, $4.4 \mathrm{~km}$ in diameter, is the main tectonic feature in Bora Bora (Fig. 1c). It is bounded by crests (up to $727 \mathrm{~m}$ high) and volcanic islets, called "Motus".

The pegmatoid Cloche de Hiro intrusion crops out in the southern part of one of these "Motus" (Motu Toopua: Fig. 1c). It is a thick dyke (250 $\mathrm{m}$ long and $120 \mathrm{~m}$ wide) crosscut by the boundary fault of the caldera (Fig. 1C). In its inner part, there are $\mathrm{N} 30^{\circ} \mathrm{E}$ to $\mathrm{N} 40^{\circ} \mathrm{E}$-trending (following the great axis of the intrusion), $1 \mathrm{~m}$-spaced vertical cracks (Fig. 1c). From the peripheral zones to the axial part, the intrusion exhibits a textural zonation from an heterogranular/intergranular gabbro (BBG-8 and -10: Fig. 2 C) to a pegmatoid rock (BBG-3B, -4 , and -5 : Fig. 2 d) through a texturally intermediate one (BBG2 and $-6 \mathrm{~B})$.

Plagioclases are the main mineral phase (from 37 to 58 vol.\%). Their chemical composition varies according to the rock texture $\left(A n_{25-55}\right.$ in pegmatoid samples, $A n_{40-70}$ in the other ones). Alkali feldspars (4 - 8 vol.\%, $\mathrm{Or}_{37-62}$ ) occur as interstitial minerals or as overgrowths on plagioclases. Clinopyroxenes are the major ferromagnesian phase within the intrusion (from 21 to 32 vol.\%). In nonpegmatoid and texturally intermediate samples, they are slightly zoned diposides ( $72 \leq \mathrm{Mg} \# \leq 87)$. In pegmatoids, the zonation of the clinopyroxenes is much more marked: crystal cores are ferrous diopside (62 $\leq \mathrm{Mg \#} \leq 78$ ) and rims are hedenbergite (34 $\leq \mathrm{Mg \#} \leq 50)$. Olivine, always HTI free, is marginal (from 2 to 5 vol.\%) except in the peripheral gabbroic sample BBG-10, in which this mineral represents $18 \mathrm{vol} . \%$. It is more ferrous in the pegmatoid samples $\left(\mathrm{FO}_{37-59}\right)$ than in the other ones $\left(\mathrm{FO}_{54}\right.$ 78). Minor phases are apatite (included in plagioclase crystals) and ferrous biotite (late crystallization around Fe-Ti oxides).

Pegmatoid samples from the Cloche de Hiro intrusion exhibit two kinds of vesicles. First, segregation vesicles (2 - 8 modal vol.\%) filled by altered microlitic or cryptocrystalline magmatic material (mainly alkali feldspars $\mathrm{Or}_{45-60}$ associated with hedenbergite or aegirine augite). These vesicles are similar to those described in pegmatoid segregation structures within HTI-bearing effusive bodies and named "V4" in the terminology proposed by Caroff et al. (2000). The other kind of vesicles are spherical amygdules, up to $1.5 \mathrm{~cm}$ in diameter, mainly filled by zeolites.

Seven samples representative of the different textural facies within the Cloche de Hiro intrusion have been analysed for major and trace elements (Table 1). In the TAS diagram of Le Bas et al. (1986), chemical compositions and textures are correlated (Fig. 3): non-pegmatoid samples are alkali basalts or K-trachybasalts whereas the other ones are K-trachybasalts or tephrites. We can also notice that the Cloche de Hiro pegmatoids are the most silica-undersaturated rocks in Bora Bora (1.80 wt.\% < $n_{\mathrm{N}}$ : Blais et al., 2000). Trace elements contents appear to be strongly correlated to the texture of the 
corresponding samples (Table 1). The pegmatoids (BBG-3B, -4 , and -5 ) are systematically the richest rocks in all incompatible trace elements. On the contrary, the heterogranular gabbroic samples (BBG8 and -10 ) exhibit contents 1.5 to 2 times lower. The chondrite-normalized REE diagram (Fig. 4b) shows that the patterns of the Cloche de Hiro coarse-grained rocks are remarkably parallel with each other. This feature suggests that the chemical variability observed within the dyke results from a fractional crystallization process.

In the diagram of Fig. 4 inset, La content (here considered as a marker of the chemical evolution) is plotted versus the maximum olivine elongation value $\left(E_{O I} \max \right)$, indicative of the importance of the pegmatoid character (see later in the text). The positive correlation between the two parameters confirms the strong connection existing between the differentiation degree and the texture: the more a rock is pegmatoidic, the more it is differentiated. 


\section{Discussion}

\subsection{Pegmatoid textures: proposition of a tetrahedral classificatory scheme}

Caroff et al. (2000) have shown that HTI is commonly associated with pegmatoids. The HTIbearing rocks, generally diktytaxitic, contain frequently pegmatoid segregation structures such as cylinders, veins or sheets. However, the corresponding texture have never been clearly characterized and no study has tackled the question of the morphological connections between the pegmatoid texture and the other coarse-grained textures. In addition, origin of the pegmatoids is still debated. We propose here a semi-quantitative textural classification scheme, derived from that proposed by Cordier et al. (2005) for the other coarse-grained rocks, as a preliminary to a genetic discussion.

The Cloche de Hiro dyke (Bora Bora) display exceptional textural features. It exhibits transitions between heterogranular textures (intermediate between equigranular and intergranular end-members: Fig. 2c) and typical pegmatoids (Fig. 2d). The classification scheme that we propose will be used to precisely caracterise the textural diversity of this dyke.

Cordier et al. (2005) have proposed a semi-quantitative textural classification scheme of the nonpegmatoid and non-cumulative coarse-grained rocks (granular / doleritic textures). The corresponding terminology turns on three end-members, each of them being characterized by a specific combination of easily measurable cristallographic parameters. The resulting triangular scheme forms the basis of the tetrahedral textural classification of coarse-grained rocks that we propose in Fig. $7 \mathrm{a}$. In addition to specific features (mineral elongation, skeletal crystals...), the pegmatoid samples from Bora-Bora display clearly textural characteristics recalling those of the pure granular / doleritic rocks: crystal of similar length in contact with each other through a side-by-side relationship for the equigranular texture; isolated spaces between the coarsest touching grains filled by smaller minerals for the intergranular texture; systematic occurrence of including grain interrelations for the oikocrystic texture. Thus, granular / doleritic features are yet identifiable in rocks exhibiting specific pegmatoid characteristics. Consequently, pegmatoid textures can be also arranged in a triangle, which can be stacked and connected to the granular / doleritic one to form the Fig. 7a tetrahedral organization (lower triangle: granular / doleritic rocks; upper triangle: pegmatoids). The top of this tetrahedron is materialized by the "glass" end-member. Indeed, the segregation materials observed within the HTIbearing lava flows exhibit frequently textural characteristics intermediate between pegmatoids and glass (GAC texture, i.e. Glass with large Acicular Crystals: Caroff et al. 2000). In addition, pegmatoid sheets contain usually cryptocrystalline patches, interpreted by Caroff et al. (2000) as previously glassy segregation vesicles (Fig. 2d).

Very simple cristallographic parameters have been measured on digitized images of selected thin sections. We have checked that, whatever is the orientation of the section, it exhibits systematically randomly oriented crystals, with the result that simple representative 2D sections can be used to acquire all the requisite textural parameters. The images have been digitized at the University of Nantes, France (UMR $n^{\circ} 6112$ "Planétologie et Géodynamique") following a process performed by Fueten (1997) and Thompson et al. (2001). The different mineral phases and grains for a single phase are successively separated by thresholding colors and edge detection, and automated measurements on the separated grains are then performed using methods described in Launeau and Bouchez (1992) and Launeau et al. (1990, 1994).

We have first selected for the semi-quantitative study pegmatoid samples displaying features typical of the three textural end-members of the granular / doleritic rocks (equigranular, oikocrystic and intergranular textures, Fig. 7a): BBG-3B, BBG-4 and BH-14, respectively. The latter sample, basaltic andesite in composition, has been collected in the Ordovician intrusion of Bréhec (North coast of Britanny, France; Suire et al. 1991). It exhibits typical intergranular features, non-observed in the Cloche de Hiro intrusion.

The thick dyke of Bora Bora display textural gradual transitions from granular/doleritic rocks to pegmatoids. To quantify these textural transitions, the evolution of two parameters has been studied, $L_{F} / L_{P x}$ and $E_{\max }$ (Fig. 7b). Parameter $L_{i}$ (in $\mathrm{mm}$ ) is defined as the maximum length measured in the studied area for the mineral species $i$ (Px: clinopyroxene; F: feldspar). Dimensionless parameter $E$ corresponds to the degree of elongation of a given grain: $E=(a-b) /(a+b)$; $a$ and $b$ (in $\mathrm{mm}$ ) correspond respectively to the great and the small axis of the inertia tensor ellipse, which is the best fit ellipse for a crystal. $E$ tends toward 1 as the elongation increases. The Fig. $7 \mathrm{~b}$ diagram corresponds to the projection of the Fig. 7a tetrahedron on the doleritic side.

According to increasing maximum olivine elongation ( $\mathrm{E}_{\mathrm{OI} \text { max }}$ ) toward the top of the tetrahedron, the samples from Bora Bora can be divided into three groups (Fig. 7b): i) the non-pegmatoid samples BBG-8 and -10 are equigranular and close to the intergranular end-member, respectively; ii) the transitional samples BBG-2 and -6B have equigranular and intergranular textures, respectively; and iii) the pegmatoids BBG-3B and BBG-4 are, respectively, equigranular and oikocystic. 
A correlation exists between the location of the samples in the Cloche de Hiro intrusion and their textural characteristics. Indeed, the granular/doleritic samples (BBG-8 and -10) are located in the southwestern extremity of the magma body, whereas the intermediate and pegmatoid rocks (BBG-2, $3 B,-4$ and $-6 B$ ) have been sampled in the northeast (Fig. 1C). Note that this part of the dyke does not correspond to its termination: the intrusion is there bounded by the caldera fault (Fig. 1C). In this area, a textural transition from intermediate textures to pegmatoids can be observed from the margins to the axial part of the dyke (from BBG-2 to BBG-3B and -4).

The presence of streched and/or skeletal crystals in pegmatoids, often associated with cryptocrystalline or glassy patches, are thought to be the consequence of crystallization under conditions of high undercooling coupled with high volatile contents, resulting in low nucleation density and high crystal growth rate (Lofgren 1980; Goff 1996; Sisson and Bacon 1999). Puffer and Horter (1993) suggest that the low crystalline density in pegmatoids occurring in the upper part of lava flows could be due to the fact that any early generation of crystal nuclei in segregation melt would fuse during ascent through the high-temperature central liquid part of the partly solidified flows. In Bora Bora, the presence of pure pegmatoids only in the central part of the dyke suggests that the volatile content increased in the crystallizing magma toward the inner part of the dyke, as a result of the progression of the solidification front.

\subsection{HTI as oxi-hydroxylated olivine}

\subsubsection{Fe3+ in HTI: a laihunitization process?}

Our study shows that HTI from Maupiti cannot include a cryptocrystalline aggregate similar to that detected by Goff $(1977,1996)$. However, our X-ray diffraction data has shown that HTI includes ferric oxides (maghemite and/or magnetite). Although low, their amounts are significative and are not the result of sample processing contamination. Our observations are rather consistent with the results of experimental high-temperature olivine oxidation in the air (e.g. Haggerty and Baker 1967, Champness 1970, Wu and Kohlstedt 1988, lishi et al. 1997). These studies have shown that, at temperatures from $600^{\circ} \mathrm{C}$ to $1100^{\circ} \mathrm{C}$, olivine oxidation results in formation of hematite \pm magnetite (50-100 $\AA$ to $0.2 \mu \mathrm{m}$ precipitates: Champness 1970) \pm amorphous silica (undetectable by X-ray diffractometry).

The presence of ferric oxides highly suggests that a significant part of Fe is oxidized within HTI, but direct in situ measurements of $\mathrm{Fe}_{2} \mathrm{O}_{3}$ contents are impossible by electron microprobe and SEM. Consequently, we have used, to estimate the $\mathrm{Fe}^{3+} / \Sigma \mathrm{Fe}$ ratio, an indirect method based on the $\mathrm{Mn}$ contents. The diagram of Fig. 8 presents the variation of $\mathrm{Mn}$ vs. Fe (cations per olivine formula unit) in dark-red "magnesian" HTI rings (I- and II-A2, III-A) and in fresh olivine (I- and II-R, II- and III-C, and olivines from HTI-free samples) from the Barque de Hiro intrusion. There is a broad positive correlation between $\mathrm{Mn}$ and $\mathrm{Fe}$ in fresh olivine, where all the iron is in the $\mathrm{Fe}^{2+}$ form. This observation is consistent with the results of Simkin and Smith (1970) and Leeman and Scheidegger (1977), who have shown that the increase of $\mathrm{Mn}$ in olivine is strongly connected to that of $\mathrm{Fe}^{2+}$. For a given $\mathrm{Fe}$ content, $\mathrm{HTI}$ is systematically depleted in Mn with respect to fresh olivine (Fig. 8). This feature would indicate that a part of $\mathrm{Fe}$ within red HTI rings is in $\mathrm{Fe}^{3+}$ state. Thus, it is possible to approximate the $\mathrm{Fe}^{3+} / \Sigma \mathrm{Fe}$ ratio within the altered areas by using the $\mathrm{Mn}$ vs. $\mathrm{Fe}^{2+}$ correlation. Indeed, $0.003 \leq \mathrm{Mn} \leq$ 0.009 within dark-red HTI should correspond to $0.45 \leq \mathrm{Fe}^{2+} \leq 0.60$ (Fig. 8). As Fe ranges between 0.68 and 0.82 , it results that $0.66 \leq \mathrm{Fe}^{2+} / \Sigma \mathrm{Fe} \leq 0.73$ and $0.27 \leq \mathrm{Fe}^{3+} / \Sigma \mathrm{Fe} \leq 0.34$. This simple calculation shows that, within $\mathrm{HTI}$ rings, $\mathrm{Fe}^{3+} / \Sigma \mathrm{Fe} \approx 1 / 3$. As the dark-red "magnesian" $\mathrm{HTI}$ rings, the fayalitic rust-colored areas (I- and II-A1) are relatively poor in $\mathrm{Mn}$ with respect to Fe (Table 2). Even if Simkin and Smith (1970) have noted that the $\mathrm{Mn}$ vs. Fe ${ }^{2+}$ correlation is less obvious when $\mathrm{Fo}<35$, we presume that $\mathrm{Fe}^{3+} / \Sigma \mathrm{Fe}$ is very high within fayalitic $\mathrm{HTI}$ : for the extreme values $\mathrm{Mn} \approx 0.001$ and $\mathrm{Fe} \approx$ 1.9 , a similar calculation gives a $\mathrm{Fe}^{3+} / \Sigma \mathrm{Fe}$ ratio up to 0.80 .

Several studies have shown that the presence of $\mathrm{Fe}^{3+}$ within the structure of olivine itself is possible and depends on pressure, temperature, $\mathrm{P}_{\mathrm{O} 2}$ and $\mathrm{P}_{\mathrm{H} 2 \mathrm{O}}$ (Dyar et al., 1998; Janney and Banfield, 1998; Khisina et al., 1995, 1998, 2000). The oxidization process of Fe in M1 sites is called "laihunitization" by these latter authors. This mechanism implies the creation of cation vacancies (), to preserve the charges equilibrium (Khisina et al. 2000). The resulting laihunite (oxidized olivine) has the ideal structural formula $\mathrm{Fe}^{3+}{ }_{1}\left(\mathrm{Mg}^{2+}, \mathrm{Fe}^{2+}\right)_{0.50 .5}\left[\mathrm{SiO}_{4}\right]$ ( $(\mathrm{Mg}$-free end-member of laihunite is called ferriolivine) but all the transitions can exist between pure laihunite and standard olivine. Laihunite has a distorted structure of olivine. Thus, the ratio $\mathrm{Si} /[\mathrm{Si}+\mathrm{Fe}+\mathrm{Mg}]$ ranges from 0.36 to 0.40 in laihunite (Janney and Banfield, 1998), while this paramater is about 0.33 in standard olivine. In Maupiti olivines and $\mathrm{HTI}$, the values of $\mathrm{Si} /[\mathrm{Si}+\mathrm{Fe}+\mathrm{Mg}$ ] (cations per formula unit of olivine) range from 0.332 to 0.339 for fresh olivine, from 0.280 to 0.329 for rust-colored central parts of HTI (I- and II-A1), and from 0.347 
to 0.404 for HTI rings (I- and II-A2, and III-A) (Table 2). Then, a laihunitization process can satisfactorily account for certain chemical characteristics of HTI rings.

\subsubsection{Olivine hydroxylation}

A small part of the deficit in the analytical sum (ca. 1 wt.\%) might result from an electron dispersion (SEM or electron microprobe analyses), due to surface defects of the thin section and/or to the microporosity of $\mathrm{HTI}$. Another part of the analytical deficit might result from the fact that $\mathrm{Fe}_{2} \mathrm{O}_{3}$ is expressed as $\mathrm{FeO}\left(1 \mathrm{wt} . \%\right.$ if $\mathrm{Fe}^{3+} / \Sigma \mathrm{Fe}=1 / 3,5 \mathrm{wt} . \%$ if $\left.\mathrm{Fe}^{3+} / \Sigma \mathrm{Fe}=0.80\right)$. In any case, a great part of the analytical deficit should have a geological explanation.

Whatever is the HTI chemical type, a water incorporation into olivine remains a very likely hypothesis to explain the main part of this deficit, as already suggested by Caroff et al. (2000). Even if amounts of water incorporated into standard olivine seem to not exceed 240 ppm (e.g. Jamtveit et al., 2001; Bell et al., 2003: mantle-derived crystals in kimberlites), several studies have shown that, under specific mantle thermodynamic conditions, there are hydroxyled forms of olivine in which water content exceeds 10800 ppm (Kohn, 1996; Keppler and Rauch, 2000). In these crystals, hydroxyl groups $\mathrm{OH}^{-}$ replace anions $\mathrm{O}^{2-}$ (Beran and Putnis, 1983; Kohlstedt et al., 1996; Khisina et al., 2002).

$\mathrm{HTI}$ appears under thermodynamic conditions very different from those prevailing in the mantle. However, partial replacement of $\mathrm{O}^{2-}$ by $2\left(\mathrm{OH}^{-}\right)$would satisfactorily account for the high LOI values measured in the olivine altered areas. To test the hypothesis of olivine hydroxylation in HTI, we have investigated by Near InfraRed reflectance spectroscopy (NIR) separated mineral fractions corresponding to two HTI morphological facies (MUG-12 cores and MUG-14 thin rings) together with fresh olivine crystals (MUG-10). The diagram of Fig. 9 displays a selected region $\left(4460-4250 \mathrm{~cm}^{-1}\right.$ ) of the NIR diffuse reflectance spectra of the corresponding powders. Unlike fresh olivine, the HTI spectra (especially MUG-12) exhibit an absorption band at $4340 \mathrm{~cm}^{-1}$. According to Frost et al. (2002), this band should correspond to a combination of hydroxyl stretching and translation mode deformation of $\mathrm{Fe}^{3+}-\mathrm{OH}^{-}-\mathrm{Fe}^{3+}$ units. Even if further investigations are necessary to identify the accurate mineralogical structure of $\mathrm{HTI}$, this preliminary result is important because it brings a direct evidence of the presence of $\mathrm{OH}^{-}$groups together with $\mathrm{Fe}^{3+}$ cations within the high-temperature altered areas of olivines.

\subsubsection{HTI: a model}

The dark-red HTI rings (I- and II-A2 and III-A; $42<$ Fo $<62$ ) are the most common HTI facies, present in both effusive and intrusive magmatic bodies. This group has a composition intermediate between a standard olivine and an hydroxyled laihunite. We propose the following synthetic structural formula for this $\mathrm{HTI}$ group: $\left(\mathrm{Mg}^{2+}{ }_{1} \mathrm{Fe}^{2+}{ }_{0.5} \mathrm{Fe}^{3+}{ }_{0.33}\right)\left[\mathrm{SiO}_{3.75}\left(\mathrm{OH}^{-}\right)_{0.5}\right]$. This formula respects charges equilibrium. Oxidization of $\mathrm{Fe}$ in the octahedral sites implies a slight cationic deficit $(\mathrm{Mg}+\mathrm{Fe}<2$; $\mathrm{Si} /(\mathrm{Si}+\mathrm{Mg}+\mathrm{Fe})>0.33)$. The chemical composition corresponds to that of a $\mathrm{Fo}_{54}$ olivine. The introduction of $0.5 \mathrm{OH}^{-}$in place of $0.25 \mathrm{O}^{2-}$ accounts for c. $5 \mathrm{wt} \%$, close to the measured analytical lack.

The fayalitic rust-colored HTI areas (I- and II-A1; $3<$ Fo $<37$ ) display chemical deviations systematically emphasized with respect to the dark-red $\mathrm{HTI}$ rings. Indeed, their $\mathrm{Fe}^{3+} / \Sigma \mathrm{Fe}$ ratio can reach 80 wt.\% and their analytical lack is up to $25 \mathrm{wt} . \%$. These features could reveal a more advanced oxi-hydroxylation process. However, the ratio $\mathrm{Si} /[\mathrm{Si}+\mathrm{Mg}+\mathrm{Fe}]$ is lower than 0.33 , which is a priori not consistent with a laihunitization process (Janney and Banfield, 1998). This peculiarity might be the consequence of a slight deficit in $\mathrm{Si}$ (Table 2), possibly due to a $\mathrm{Fe}^{3+}$ incorporation into the tetrahedral sites in substitution of $\mathrm{Si}^{4+}$, a likely mechanism according to Libowitsky and Beran (1995).

\subsection{The Cloche de Hiro dyke: a huge segregation structure derived from a HTI-bearing gabbro?}

One of the best examples of association HTI-segregations in effusive bodies is the Bouzentès 5- to 30-m-thick vesicle-rich alkali basalt flow (Cantal, France: Caroff et al., 1997). The texture of the lava host is both finely doleritic and diktytaxitic. Olivine phenocrysts exhibit systematically thin HTI rings (III-A type, Fig. 5d). The upper part of the lava flow has, up to $4 \mathrm{~m}$ beneath the top, 1- to $20-\mathrm{cm}-$ thick vesiculated sheets, hawaiitic in composition and pegmatoid in texture (S3 sheets in the terminology of Caroff et al., 2000). These sheets are devoid of HTI-bearing olivine crystals, but they contain numerous segregation vesicles completely filled with phonolitic cryptocrystalline material (Caroff et al., 1997). Following these authors, the formation of the Bouzentès vesicle-rich pegmatoids is due to a vapor-differentiation mechanism. After cessation of lava movement, vesiculated diapirs of residual melt formed above the lower solidification front and moved upward. Below the crust-melt 
upper boundary, vesicles and liquid spread out to form the sheets. Finally, segregation liquid, impoverished in crystal nuclei because a part of them fused during ascent through the hightemperature central part of the flow, crystallized as large pegmatitic crystals under high undercooling conditions.

The textural and mineralogical features of the Maupiti pegmatoid enclave MUG-6B (see earlier in the text) resemble to those described in the Bouzentès pegmatoid sheets (Caroff et al, 1997), except for the vesicles (empty and segregation vesicles) which are lacking in the Maupiti segregation. As in the Bouzentès case, the pegmatoid enclave MUG-6B is chemically more evolved than the host magma (Fig. 3) and its REE pattern is parallel to the patterns of the Faataufi gabbros (Fig. 4a).

The Cloche de Hiro pegmatoid dyke from Bora Bora has textural, petrological, and (major element) chemical characteristics extremely similar to the Bouzentès pegmatoids: minerals are the same in both sites; they show similar abnormal crystallization features and have comparable size; we note in Bouzentès and in Bora Bora the presence of both amygdules and cryptocrystalline segregation vesicles; pegmatoids of both localities have undergone a rather equivalent extent of differentiation. This huge pegmatoid intrusion seems to be disconnected from any diktytaxitic body, an attribute very unusual with respect to the other pegmatoids described in the literature. This is the reason why we propose that the Cloche de Hiro dyke is merely the exposed part of a more important intrusive complex, maybe HTI bearing. In Fig. 10, we compare the Bouzentès lava flow with $a$ postulated mafic complex, which associates the Faataufi intrusion and the Cloche de Hiro dyke. In this view, the Cloche de Hiro pegmatoid would correspond to a huge segregation structure derived from a Faataufi-type HTI-bearing gabbro. The corresponding magmatic system would be an equivalent to the Bouzentès lava flow, at a larger scale, i.e. a vertically arranged complex. The intervention of a vapordriven differentiation mechanism to form the giant segregation body is very likely, as suggested by: (1) the abundance of empty vesicles, amygdules and segregation vesicles in the Cloche de Hiro pegmatoid; (2) the presence of $\mathrm{HTI}$ in the Faataufi gabbro, together with (3) a diktytaxitic structure. The combination of these three points has constantly been regarded as the key for the vapor-driven hypothesis (Caroff et al., 1996; Goff, 1996; Caroff et al., 2000). Vesicle-rich residual melt would be expelled from a lower HTI-bearing gabbroic solidification zone by the build-up of gas pressure, before gather into a shallow level and crystallize there as a pegmatoid body, under conditions of high undercooling coupled with high volatile contents (Fig. 10). The Maupiti vesicle-free pegmatoid MUG6B might correspond also to a segregation stucture, but formed through another mechanism such as filling of cracks formed within a crystalline mush as a result of thermal contraction associated with cooling and shrinkage (Greenough and Dostal, 1992) or filling of a dilatation zone by a liquid coming from a compacted mushy area (Philpotts et al., 1996).

\section{Acknowledgements}

Very detailed and constructive comments by $\mathrm{Dr}$ Wendy Bohrson and an anonymous reviewer helped us a lot to improve the manuscript. We thank also Dr Stephen Foley for his editorial assistance. Field studies were conducted in 1999 with the financial support of DIRCEN, CEA, and BRGM. This is the contribution $\mathrm{n}^{\circ} \mathrm{xx}$ of the IUEM, European Institut for Marine Studies (Brest, France). 


\section{References}

Bell, D.R., Rossman, G.R., Maldener, J., Endisch, D., Rauch, F., 2003. Hydroxide in olivine : a quantitative determination of the absolute amount and calibration of the IR-Spectrum. J. Geophys. Res. 108, 2105-2113.

Beran, A., Putnis, A., 1983. A model of the hydroxyl positions in olivine, derived from infraredspectroscopic investigations. Phys. Chem. Miner. 9, 57-60.

Blais, S., Guille, G., Guillou, H., Chauvel, C., Maury, R.C., Caroff, M., 2000. Géologie, géochimie et géochronlogie de l'île de Bora Bora (Société, Polynésie Francaise). C. R. Acad. Sci. Paris 331, 579-585.

Blais, S., Guille, G., Guillou, H., Chauvel, C., Maury, R.C., Pernet, G., Cotton, J., 2002. The island of Maupiti: the oldest emergent volcano in the Society hot spot chain (French Polynesia). Bull. Soc. Géol. France 173, 45-55.

Boyers, W.C., McMillan, N.J., Snow, P., Goff, F.E., 1996. Origin of magmatic iddingsite in tertiary volcanic rocks, NM: Geological Society of America Abstracts with Program, 1996 Annual National Meeting, Denver, CO, 484.

Caroff, M., Ambrics, C., Maury, R.C., Cotton, J., 1997. From alkali basalt to phonolite in hand-size samples: vapor-differentiation in the Bouzentès lava flow (Cantal, France). J. Volcanol. Geotherm. Res. 79, 47-61.

Caroff, M., Guillou, H., Lamiaux, M., Maury, R.C., Guille, G., Cotton, J., 1999. Assimilation of ocean crust by hawaiitic and mugearitic magmas: an example from Eiao (Marquesas). Lithos 46, 235258.

Caroff, M., Maury, R.C., Cotton, J., Clément, J.P., 2000. Segregation structures in vapor differentiated basaltic flows. Bull. Volcanol. 62, 171-187.

Champness, P.E., 1970. Nucleation and growth of iron oxides in olivines, $(\mathrm{Mg}, \mathrm{Fe})_{2} \mathrm{SiO}_{4}$. Min. Mag. $37,790-800$

Cordier, C., Clément, J.P., Caroff, M., Hémond, C., Blais, S., Cotten, J., Bollinger, C., Launeau, P., Guille, G., 2005. Petrogenesis of plutonic intrusives from Tahiti Nui and Raiatea ocean islands (Society, French Polynesia). J. Petrol., 46, 2281-2312.

Costa, A., Blake, S., Self, S., 2006. Segregation processes in vesiculating crystallizing magmas. J. Volcanol. Geotherm. Res. 153, 287-300.

Cotten, J., Le Dez, A., Bau, M., Caroff, M., Maury, R.C., Dulski, P., Fourcade, S., Bohn, M., Brousse, R., 1995. Origin of anomalous rare-earth element and yttrium enrichments in subaerially exposed basalts: Evidence from French Polynesia. Chem. Geol. 119, 115-138.

Dyar, M.D., Delaney, J.S., Sutton, S.R., Schaefer, M., 1998. Fe ${ }^{3+}$ distribution in oxidised olivine: a synchrotron micro-XANES study. Amer. Mineral. 83, 1361-1365.

Edwards, A.B., 1938. The formation of iddingsite. Amer. Min. 23, 277.

Fawcett, J.J., 1965. Alteration products of olivine and pyroxene in basalt lavas from the Isle of Mull. Min. Mag. 35, 55-71.

Foley, S.F., Jackson, S.E., Fryer, B.J., Greenough, J.D., Jenner, G.A., 1996. Trace element partition coefficients for clinopyroxene and phlogopite in an alkaline lamprophyre from Newfoundland by LAM-ICP-MS. Geochim. Cosmochim. Acta 60, 629-638.

Frost, R.L., Kloprogge, J.T., Ding, Z., 2002. Near-infrared spectroscopic study of nontronites and ferruginous smectite. Spectrochim. Acta Part A 58, 1657-1668.

Fueten, F., 1997. A computer controlled rotating polarizer stage for the petrographic microscope. Comput. Geosci. 23, 203-208.

Furgal, S.A., McMillan, N.J., 2001. Magmatic iddingsite: changes in $\mathrm{H}_{2} \mathrm{O}$ in magma chambers prior to eruption. Geological Society of America Abstracts with Program, 2001 Annual National Meeting, Boston, Massachusetts.

Gay, P., Le Maître, R.W., 1961. Some observations on "iddingsite". Am. Min. 46, 92-111.

Goff, F.E., 1977. Vesicle cylinders in vapor-differentiated basalt flows. PhD Thesis, University of California, Santa Cruz, CA, $181 \mathrm{pp}$.

Goff, F.E., 1996. Vesicle cylinders in vapor-differentiated basalt flows. J. Volcanol. Geotherm. Res. 71, 167-185.

Goode, A.D.T., 1974. Oxidation of natural olivines. Nature 248, 500-501.

Greenough, J.D., Dostal, J., 1992. Cooling history and differentiation of a thick North Mountain Basalt flow (Nova Scotia, Canada). Bull. Volcanol. 55, 63-73.

Gualtieri, A.F., Gemmi, M., Dapiaggi, M., 2003. Phase transformations and reaction kinetics during the temperature-induced oxidation of natural olivine. Am. Min. 88, 1560-1574.

Guillou, H., Blais, S., Guille, G., Maury, R.C., Le Dez, A., Cotten, J., 1998. Ages (K-Ar) et durées d'édification subaérienne des îles de Moorea, Raiatea et Maupiti (Société, Polynésie française). Géol. France 3, 29-36.

Haggerty, E.S., Baker, I., 1967. The alteration of olivine in basaltic and associated lavas. Part I: Hightemperature alteration. Contrib. Mineral. Petrol. 16, 233-257. 
Henderson, P., 1984. General geochemical properties and abundances of the rare earth elements. In: Henderson, P. (Ed), Rare earth element geochemistry, development in geochemistry 2. Elsevier, pp. 1-32.

lishi, K., Torigoe, K., Han, X.J., 1997. Oriented precipitate complexes in iron-rich olivines produced experimentally in aqueous oxidizing environment. Phys.Chem. Min. 25, 8-14.

Jamtveit, B, Brooker R, Brooks K, Larsen LM, Pedersen T (2001) The water content of olivines from the North Atlantic Volcanic Province. Earth Planet Sci Lett 186: 401-415

Janney, D.E., Banfield, J.F., 1998. Distribution of cations and vacancies and the structure of defects in oxidised intermediate olivine by atomic-resolution TEM and image simulation. Amer. Mineral. 83, 799-810.

Keppler, H., Rauch, M., 2000. Water solubility in nominally anhydrous minerals mesaured by FTIR and IHMAS NMR: the effect of sample preparation. Phys. Chem. Miner. 27, 371-376.

Khisina, N.R., Khramov, D.A., Kolosov, M.V., Kleschev, A.A., Taylor, L.A., 1995. Formation of ferriolivine and magnesioferrite from $\mathrm{Mg}$-Fe-olivine: reaction and kinetics of oxidation. Phys. Chem. Minerals 22, 241-250.

Khisina, N.R., Khramov, D.A., Kleschev, A.A., Langer, K., 1998. Laihunitization as a mechanism of olivine oxidation. Eur. J. Mineral 10, 229-238.

Khisina, N.R., Langer, K., Andrut, M., Ukhanov, A.V., Wirth, R., 2000. Nano-scale microstructure of $\mathrm{Fe}^{3+}$-, $\mathrm{OH}^{-}$-bearing crystalline inclusions in experimentally oxidized olivine from a mantle nodule. Min. Mag. 64, 319-335.

Khisina, N.R., Wirth, R., Andrut, M., 2002. Forms of occurrence of $\mathrm{OH}^{-}$in mantle olivines. 1 Structural hydroxyl. Geokhimiya 4, 375-385.

Kohlstedt, D.L., Keppler, H., Rubie, D.C., 1996. Solubility of water in the , and phases of (Mg, $\mathrm{Fe})_{2} \mathrm{SiO}_{4}$. Contrib. Mineral. Petrol. 123, 345-357.

Kohn, S.C., 1996. Solubility of $\mathrm{H}_{2} \mathrm{O}$ in nominally anhydrous mantle minerals using ${ }^{1} \mathrm{H}$ MAS NMR. Am. Mineral. 81, 1523-1526.

Koltermann, M., 1962. Der Thermische Zerfall fayallithaltinger Olivine bai hohen Temperaturen. Neues Jahrbuch Mineralogie Monatshelfte, 181-191.

Lacroix, A., 1904. La Montagne Pelée et ses éruptions. Masson, Paris

Launeau, P., Bouchez, J.L., Keith, B., 1990. Shape preferred orientation of object population: automatic analysis of digitized images. Tectonophysics 180, 201-211.

Launeau, P., Bouchez, J.L., 1992. Mode et orientation préférentielle de forme des granites par analyse d'images numériques. Bull. Soc. Géol. France 163, 721-732.

Launeau, P., Cruden, A.R., Bouchez, J.L., 1994. Mineral recognition in digital images of rocks: a new approach using multichannel classification. Can. Mineral. 32, 919-933.

Le Bas, M.J., Le Maitre, R.W., Streckeisen, A., Zanettin, B., 1986. A chemical classification of volcanic rocks based on the total-alkali silica diagram. J. Petrol. 27, 745-750.

Leeman, W.P., Scheidegger, K.F., 1977. Olivine/liquid distribution coefficients and a test for crystalliquid equilibrium. Earth Planet. Sci. Lett. 35, 247-257.

Lemaitre, O., Brousse, R., Goni, J., Remond, G., 1966. Sur l'importance de l'apport de fer dans la transformation de l'olivine en iddingsite. Bull. Soc. Franç. Miner. Crist. 89, 477-483.

Lemarchand, F., Villemant, B., Calas, G., 1987. Trace element distribution coefficients in alkaline series. Geochim. Cosmochim. Acta 51, 1071-1081.

Libowitsky, E., Beran, A., 1995. OH defects in forsterite. Phys. Chem. Min. 22, 387-392.

Lofgren, G., 1980. Experimental studies on the dynamic crystallization of silicate melts. In: Hargraves, R.B. (Ed.), Physics of magmatic processes. Princeton University Press, Princeton, pp. 487551.

Merle, R., Caroff, M., Girardeau, J., Cotten, J., Guivel, C., 2005. Segregation vesicles, cylinders, and sheets in vapor-differentiated pillow lavas: Examples from Tore-Madeira Rise and Chile Triple Junction. J. Volcanol. Geotherm. Res. 141, 109-122.

Middlemost, E.A.K., 1989. Iron oxydation ratios, norms and the classification of volcanic rocks. Chem. Geol. 70, 19-29.

Philpotts, A.R., Carroll, M., Hill, J.M., 1996. Crystal mush compaction and the origin of pegmatitic segregation sheets in a thick flood basalt flow in the Mesozoic Hartford Basin, Connecticut. J. Petrol. 37, 811-836.

Philpotts, A.R., Shi, J., Brustman, C., 1998. Role of plagioclase crystal chains in the differentiation of partly crystallized basaltic magma. Nature 395, 343-346.

Puffer, J.H., Horter, D.L., 1993. Origin of pegmatitic segregation veins within flood basalts. Geol. Soc. Am. Bull. 105, 738-748.

Rogan, W., Blake, S., Smith, I., 1996. In situ chemical fractionation in thin basaltic lava flows: examples from the Auckland volcanic field, New Zealand, and a general physic model. J. Volcanol. Geotherm. Res. 74, 89-99. 
Schandl, E.S., Gorton, M.P., Wicks, F.J., 1990. Mineralogy and geochemistry of alkali basalts from Maud Rise, Weddell Sea, Antarctica. In: Barker, P.F., Kennett, J.P. et al. (Eds.), Proc. ODP Sci. Results 113, pp. 5-14.

Schenato, F., Formoso, M.L.L., Dudoignon, P., Meunier, A., Proust, D., Mas, A., 2003. Alteration processes of a thick basaltic lava flow of the Paraná Basin (Brazil): petrographic and mineralogical studies. J. South Am. Earth Sci. 16, 423-444.

Self, S., Thordarson, T., Keszthelyi, L., Walker, G.P.L., Hon, K., Murphy, M.T., Long, P., Finnemore, S., 1996. A new model for the emplacement of Columbia River basalts as large, inflated pahoehoe lava flow fields. Geophys. Res. Lett. 23, 2689-2692.

Self, S., Thordarson, T., Keszthelyi, L., 1997. Emplacement of continental flood basalt lava flows. Geophys. Monogr. 100, 381-410.

Sigmarsson, O., Thordarson, T., Jakobsson, S.P., 2005. Segregation veins in Surtsey lavas, Iceland: implications for volatile-melt induced magma differentiation. Geophys. Res. Abstr. 7, 10272.

Simkin, T., Smith, J.V., 1970. Minor-element distribution in olivine. J. Geol. 78, 304-325.

Sisson, T.W., Bacon, C.R., 1999. Gas-driven filter pressing in magmas. Geology 27, 613-616.

Suire, P., Dabard, M.P., Chauvel, J.J., 1991. Nouvelles données sur les séries rouges nordarmoricaines: étude du bassin ordovicien de Bréhec. C. R. Acad. Sci. Paris 312, 721-727.

Sun, S.S., McDonough, W.F., 1989. Chemical and isotopic systematics of oceanic basalts: implication for mantle composition and processes. In: Saunders, A.D. and Norry, M.J. (Eds.), Geological Society Special Publication, Vol. 42, Magmatism in the Ocean Basins. Blackwell, London, pp. 313-345.

Thompson, S., Fueten, F., Bockus, D., 2001. Mineral identification using artifical neural networks and the rotating polarizer stage. Comput. Geosci. 27, 1081-1089.

Thordarson, T., Self, S., 1998. The Roza Member, Columbia River Basalt Group: a gigantic pahoehoe lava flow field formed by endogenous processes. J. Geophys. Res. 103, 27411-27445.

Wacaster, S.G., McConnell, V.S., 2002. Segregation structures in diktytaxitic basalt flows of NE Oregon. The Geological Society of America, Cordilleran Section - $98^{\text {th }}$ Annual Meeting (May 13-15, 2002), Corvallis, Oregon, USA.

Waichel, B.L., de Lima, E.F., Lubachesky, R., Sommer, C.A., 2006. Pahoehoe flows from the central Paraná Continental Flood Basalts. Bull. Volcanol. 68: 599-610.

Wu, T., Kohlstedt, D.L., 1988. Rutherford backscattering spectroscopy study of (Mg, $\mathrm{Fe})_{2} \mathrm{SiO}_{4}$. J. Am. Ceram. Soc. 71, 540-545. 


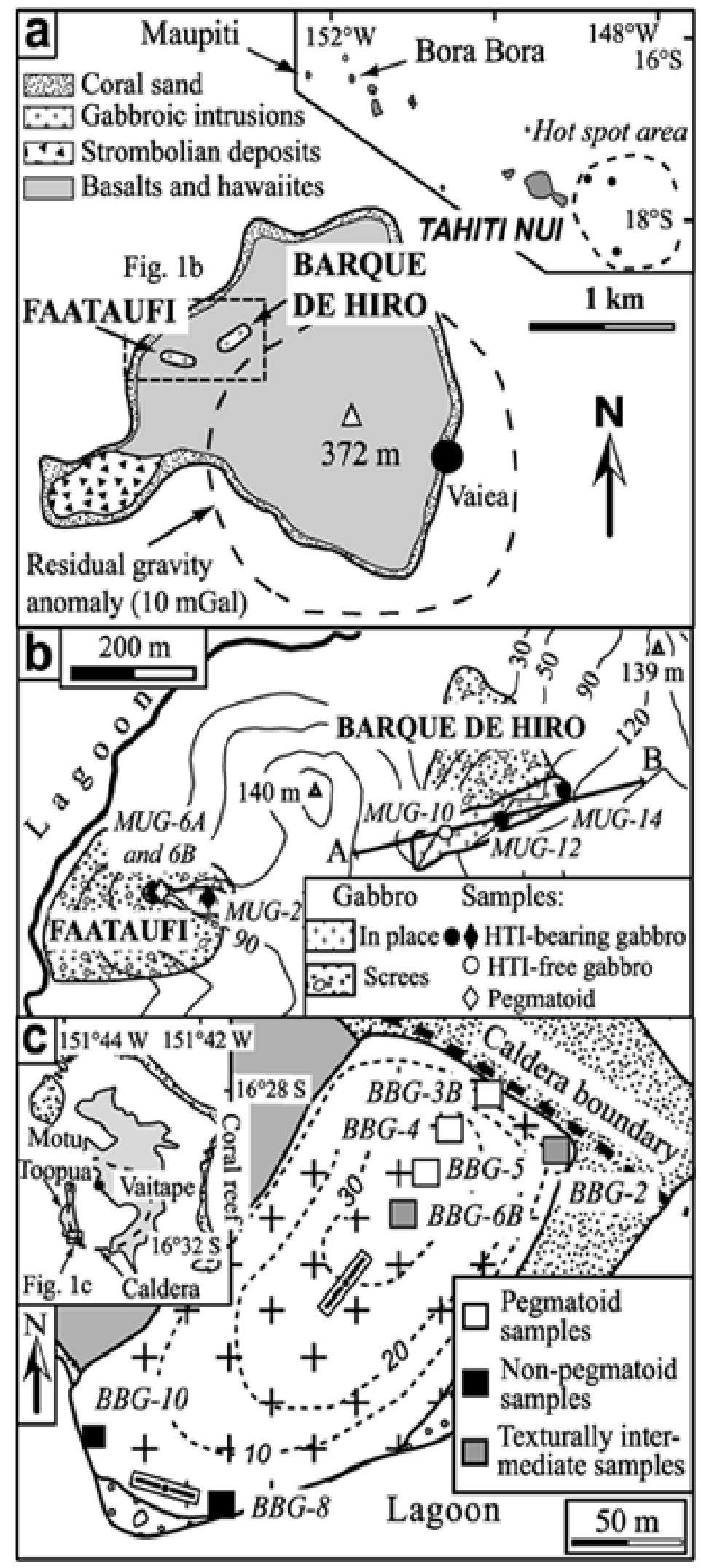

Fig. 1. (a) Geological map of Maupiti island (modified after Blais et al., 2002) showing the location of the two gabbroic intrusions: Faataufi and Barque de Hiro; inset: Society Archipelago. (b) Sketch map of the gabbroic intrusions area, in the northwestern part of Maupiti, with key-sample location. (c) Geological map of the Cloche de Hiro pegmatoid dyke (Bora Bora island) showing the sample location and the orientation of the vertical cracks materializing the magma flowing direction (in the rectangular boxes); inset: Bora Bora sketch map and location of the dyke. 


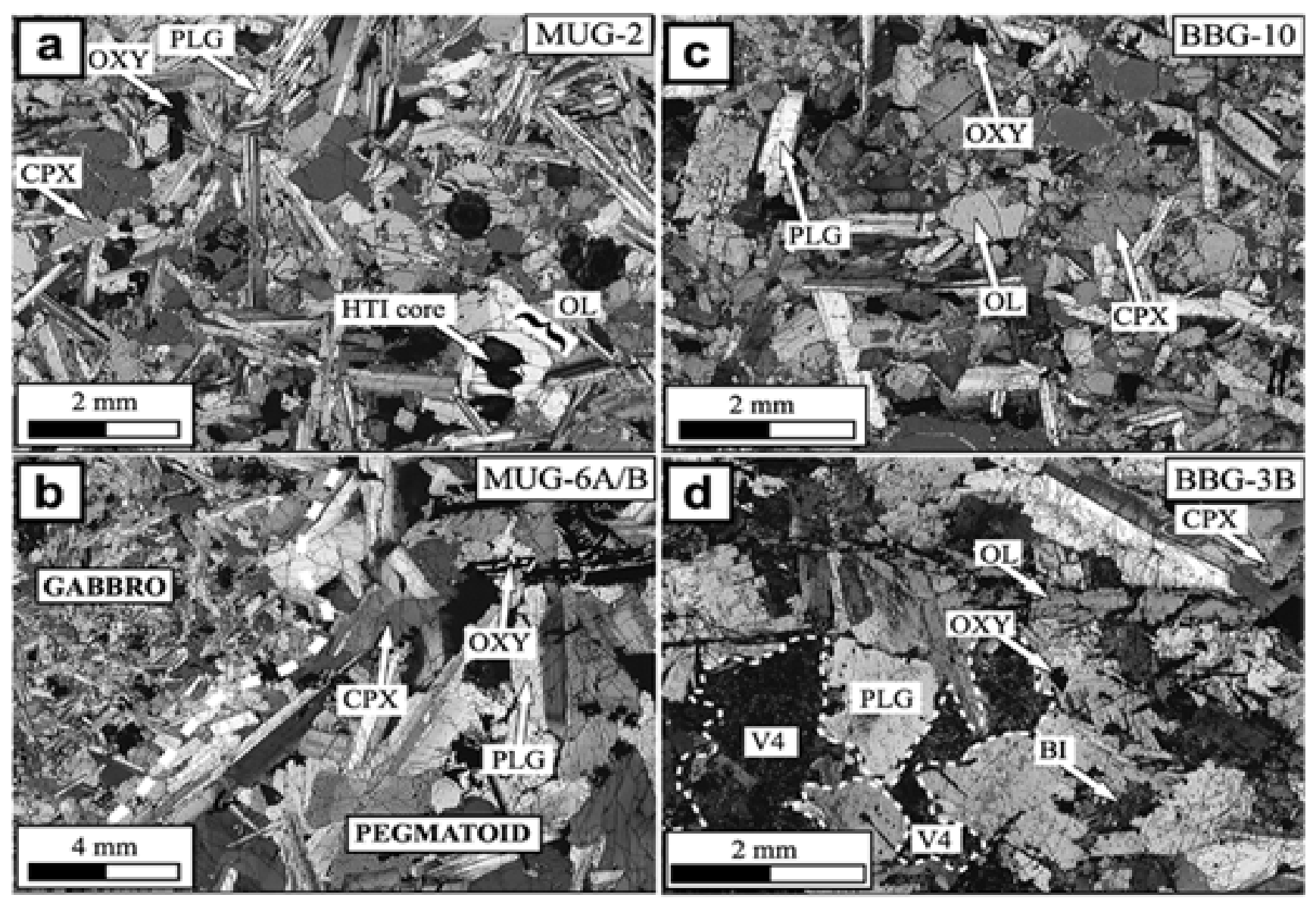

Fig. 2. Photomicrographs (crossed nicols) of the textural features in the gabbroic and pegmatoid samples from Maupiti and Bora Bora intrusions. (a) Sample MUG-2 (HTI-bearing gabbro; Faataufi intrusion, Maupiti). The gabbro displays a typical equigranular texture; HTI occurs as rust-colored cores (type I of Fig. 5). CPX clinopyroxene; OL, olivine; OXY, Fe-Ti oxides; PLG, plagioclase. (b) Contact (white dashed line) between samples MUG-6A and -6B (gabbro and pegmatoid enclave, respectively; Faataufi intrusion, Maupiti). The coarser-grained pegmatoid exhibits large and elongated plagioclase and clinopyroxene crystals, acicular and/or skeletal Fe-Ti oxides, and anhedral olivine crystals, sometimes with HTI cores. (c) Sample BBG-10 (doleritic sample; Cloche de Hiro intrusion, Bora Bora) This HTI-free sample, located at the periphery of the intrusion, displays a typical intergranular doleritic texture. Some large grains of clinopyroxene coexist with some smaller ones, which occupy the interstices between the plagioclase laths. (d) Sample BBG-3B (pegmatoid; Cloche de Hiro intrusion, Bora Bora). This sample has an equigranular pegmatoid texture. The photomicrograph shows an abnormally elongated olivine crystal and V4-type segregation vesicles, filled by a microlitic residual liquid (mainly alkali feldspars and hedenbergite or aegirine augite). $\mathrm{Bl}$, biotite. 


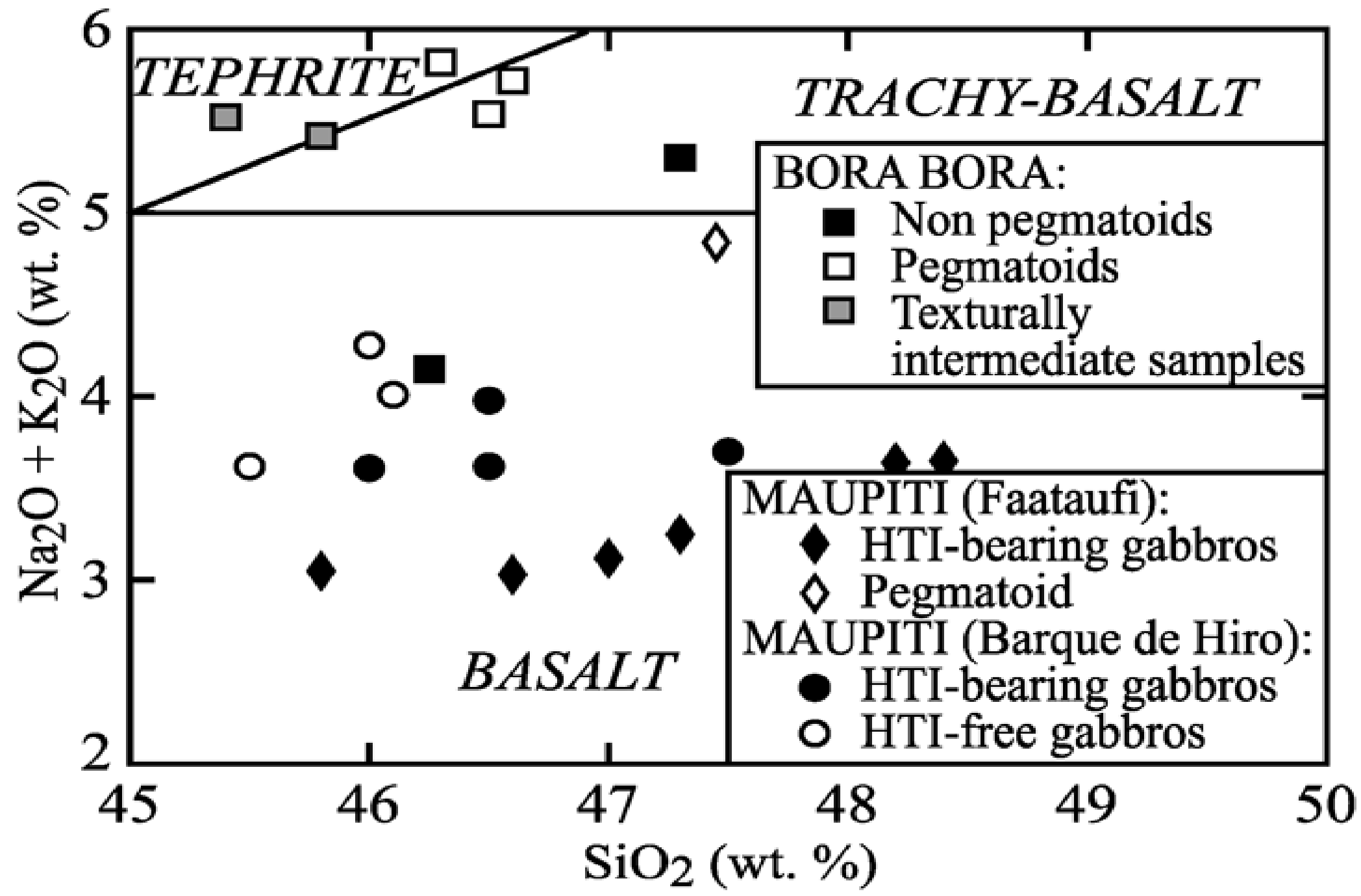

Fig. 3. Total alkali-silica (TAS) discrimination diagram from Le Bas et al. (1986) for the gabbroic and pegmatoid samples from the three intrusions studied here. 


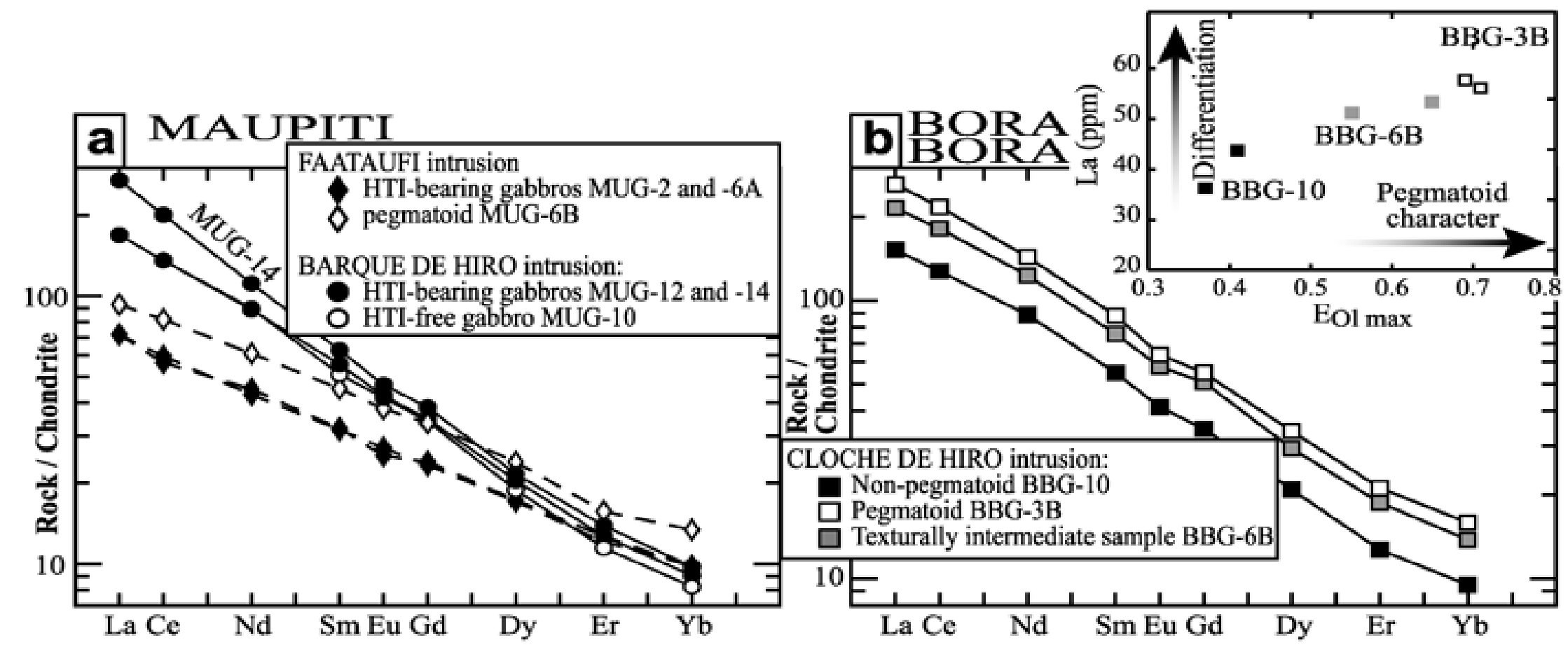

Fig. 4. Chondrite C1-normalised rare earth elements (REE) patterns of selected Maupiti and Bora Bora samples. (a) Gabbroic and pegmatoid samples from Barque de Hiro and Faataufi intrusions (Maupiti). (b) Pegmatoid samples from the Cloche de Hiro dyke (Bora Bora). Normalisation values are from Sun and McDonough (1989). Inset: plot of La (ppm) versus EOI max (maximum olivine elongation value) for the Cloche de Hiro samples. 


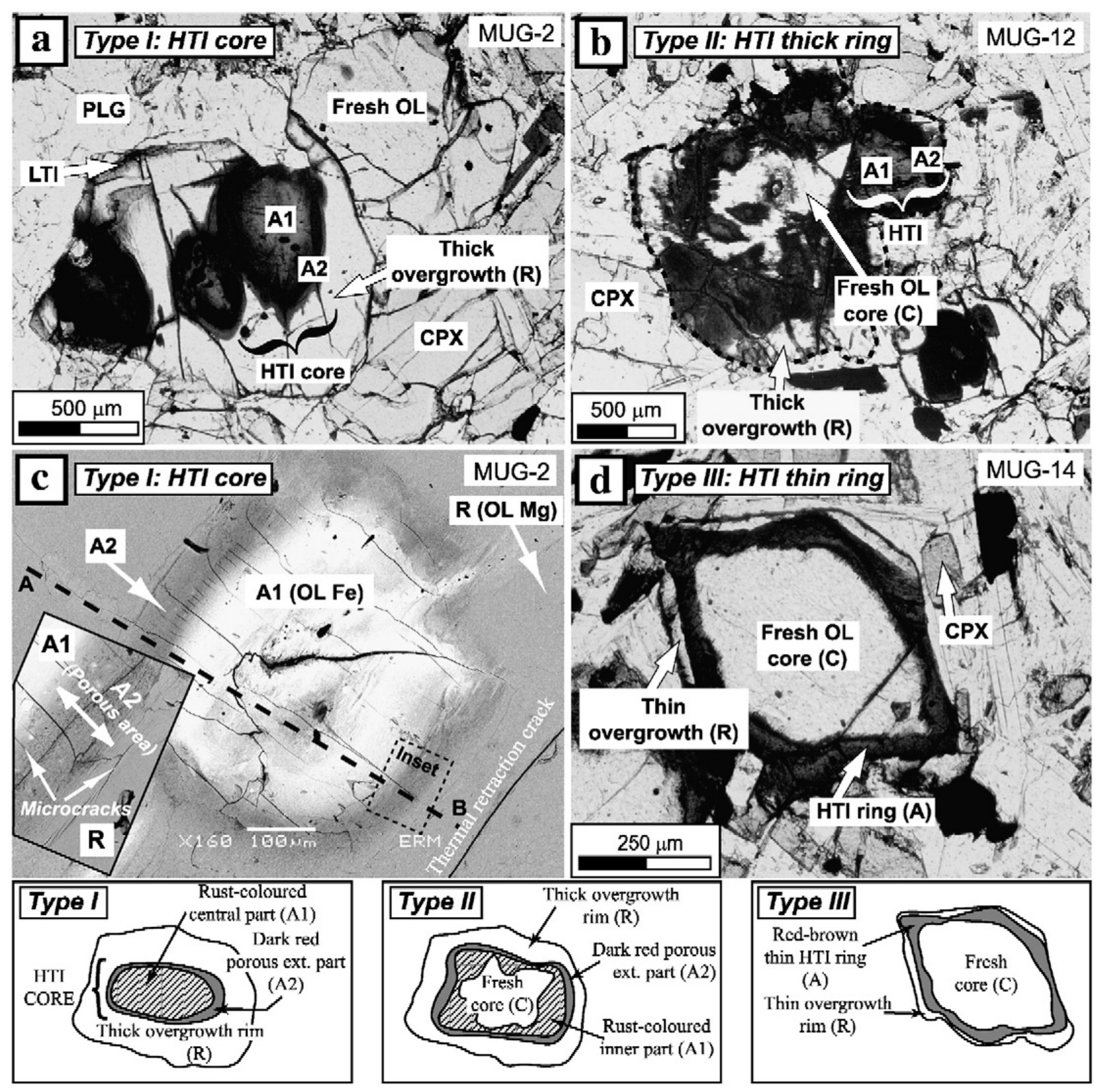

Fig. 5. Photomicrographs of the three HTI morphological types observed within the Maupiti gabbroic intrusions. The cartoons at the bottom of the figure specify the terminology and acronyms adopted to describe details of the three facies. (a) Sample MUG-2 (Faataufi). Three rust-colored HTI cores (type I) occur within one single olivine crystal. CPX, clinopyroxene; HTI, high temperature iddingsite; LTI, low temperature iddingsite; OL, olivine; PLG, plagioclase. (b) Sample MUG-12 (Barque de Hiro). Whereas the main part of the olivine crystals in this sample contain HTI of type I, the largest ones (as the crystal rounded by a black dashed line on the photomicrograph) exhibit rust-colored HTI thick rings (type II). (c) Sample MUG-2 (Faataufi). Back-scattered electron photomicrograph, performed by a scanning electron microscope (JEOL 6400, University of Poitiers, France), of a HTI core (type I). This image allows to highlight the contrasts of chemistry and density (the emission rate of electrons is proportional to the average atomic weight of the mineral) between the (Fe-rich) I-A1 and the (Fe-poor) I-R HTI areas. Inset: detailed view of the porous external part of the HTI core (I-A2), affected by two systems of microcracks at a 90 degree angle. (d) Sample MUG-14 (Barque de Hiro). All the olivine crystals in this sample exhibits HTI thin rings (type III), similar to those observed in effusive magma bodies. 


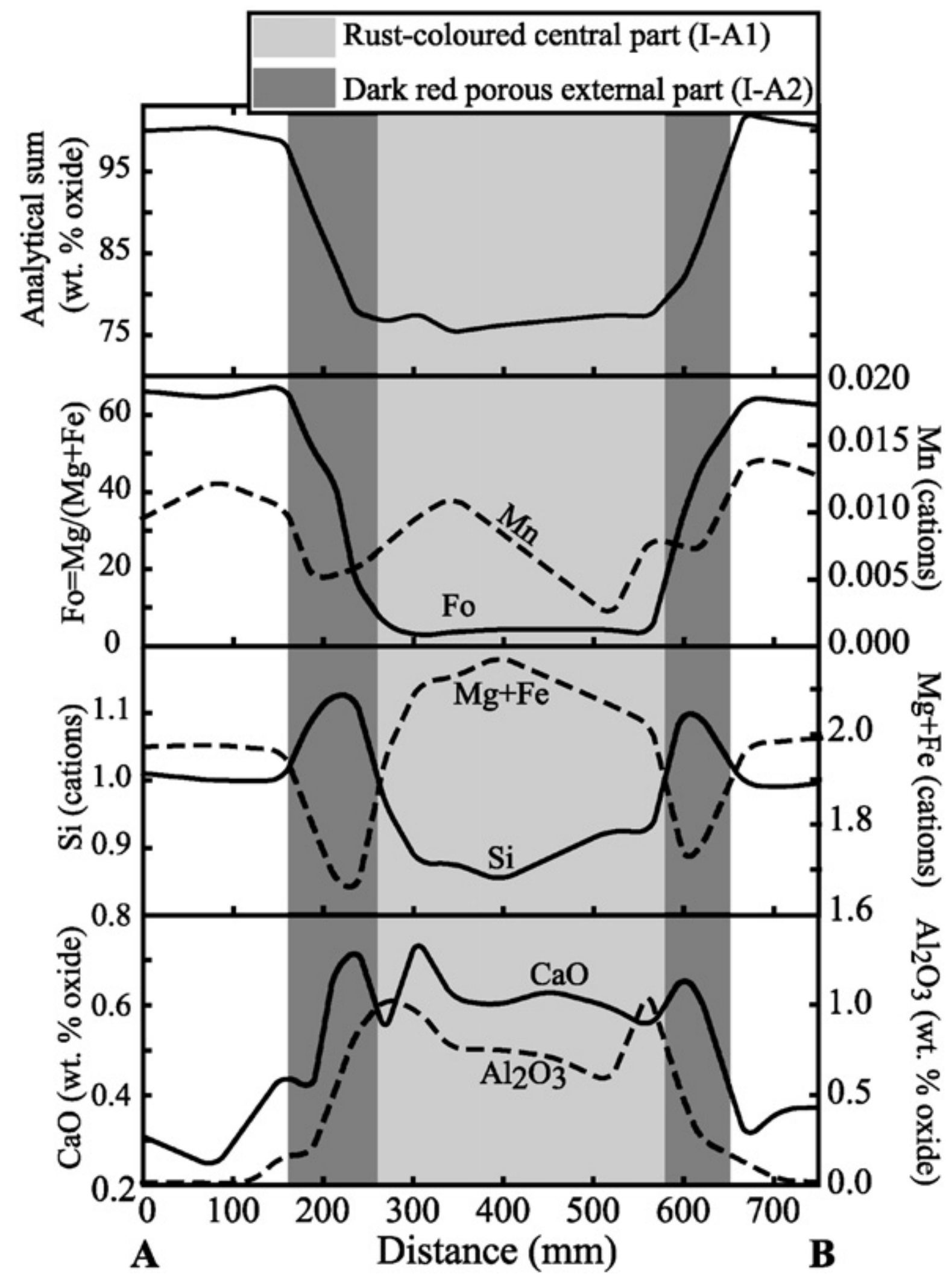

Fig. 6. Diagrams showing the variation of some chemical parameters within a single HTI core of type I, along the $750 \mathrm{~m}$-long transect shown in Fig. $5 \mathrm{c}$. Analyses have been performed with the scanning electron microscope JEOL 6400 (University of Poitiers, France). 


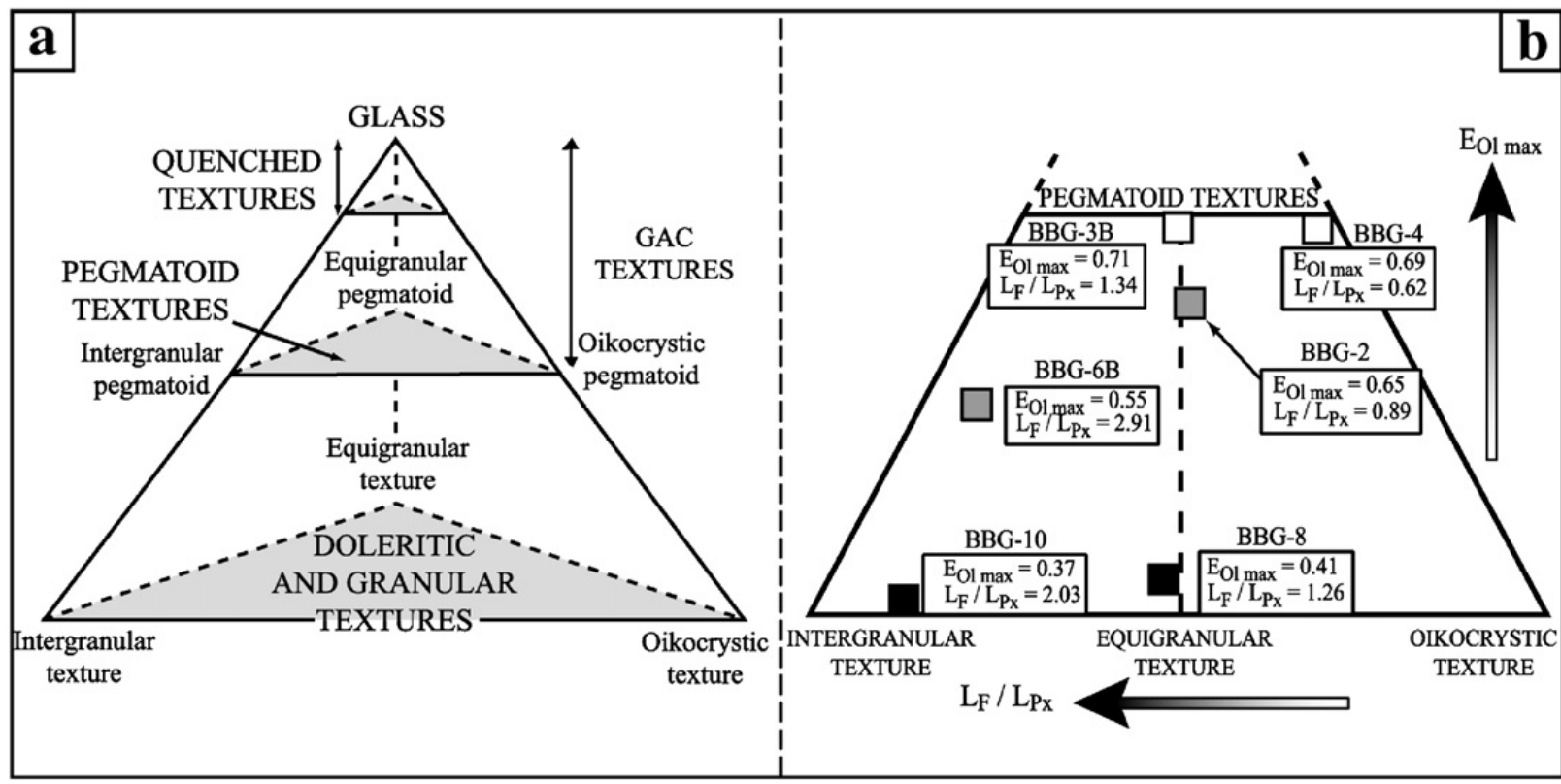

Fig. 7. (a) Tetrahedral textural classification for coarse-grained magmatic rocks connecting granular/doleritic and pegmatoid textures (see explanations in text). (b) Diagram showing the gradual transition from granular/doleritic textures to pegmatoid ones in the Cloche de Hiro dyke (Bora Bora). The diagram corresponds to the projection of the Fig. 7a tetrahedron on the intergranular-oikocrystic-glass side. Parameter $\mathrm{Li}$ (in $\mathrm{mm}$ ) is defined as the maximum length measured in the studied area for the mineral species i. LF/LPx ratios vary according to grain relations and then, can be used to plot a given sample "horizontally" on the triangular basis of the classification tetrahedron, relatively to the three textural end-members. The degree of pegmatoid overprint can be quantified through the variation of the maximum mineral elongation (Emax). This parameter allows to determine the position of a given sample "vertically" in the tetrahedron. The minerals whose elongation is, in the studied case, the most sensitive to the pegmatoid character are undoubtedly olivines (Fig. 2d). Therefore, the elongation of these minerals has been used to estimate the relative "distance" of the Bora Bora samples away from the pegmatoid triangle of (a). The points representative of each sample are plotted according to the values of both ratio LF/LPx and parameter Emax. For more explanations, see text and also Cordier et al. (2005). 


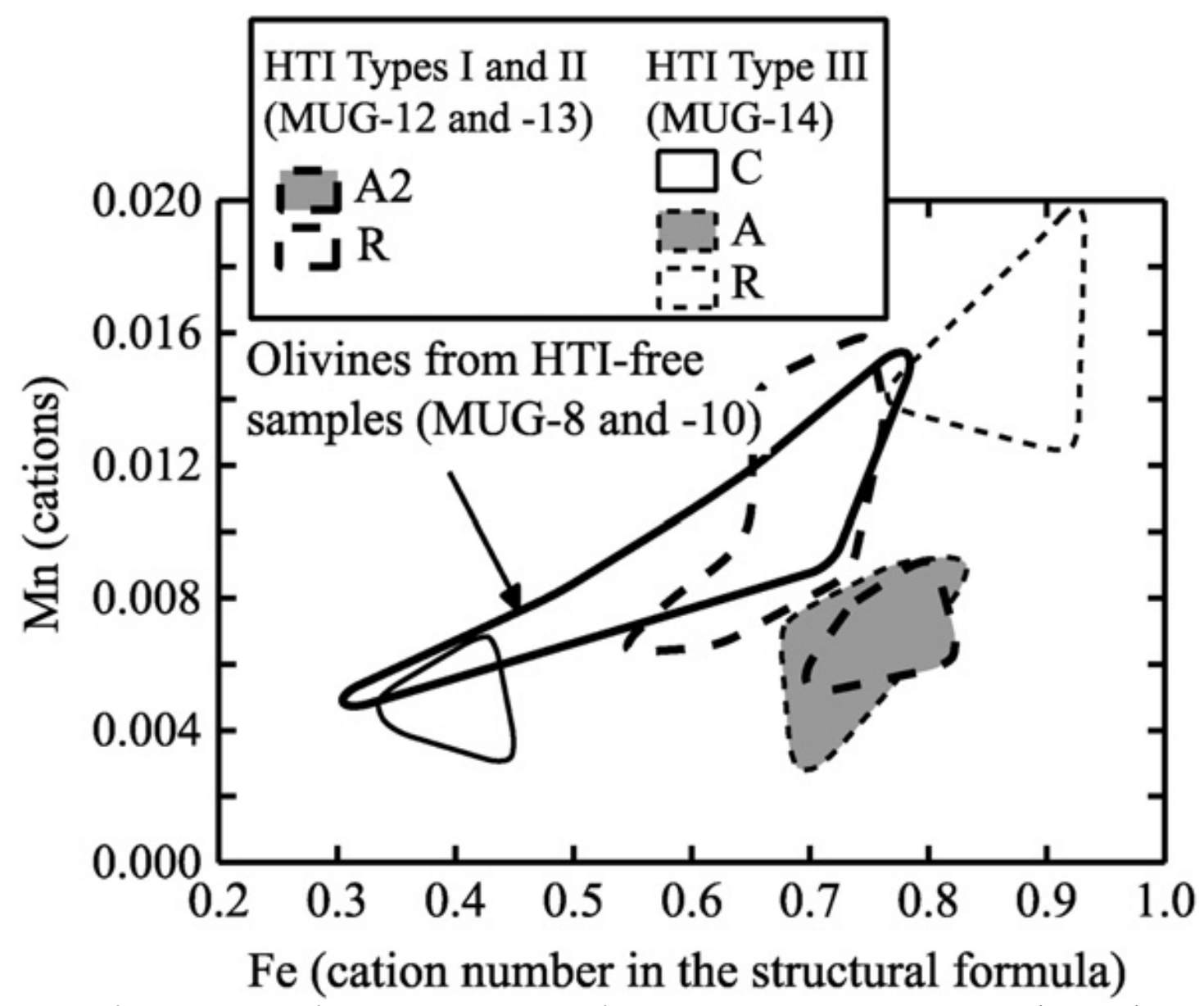

Fig. 8. Plot of Mn versus Fe for the olivine crystals from the Barque de Hiro intrusion (Maupiti). Element contents are expressed as cations per olivine formula unit.

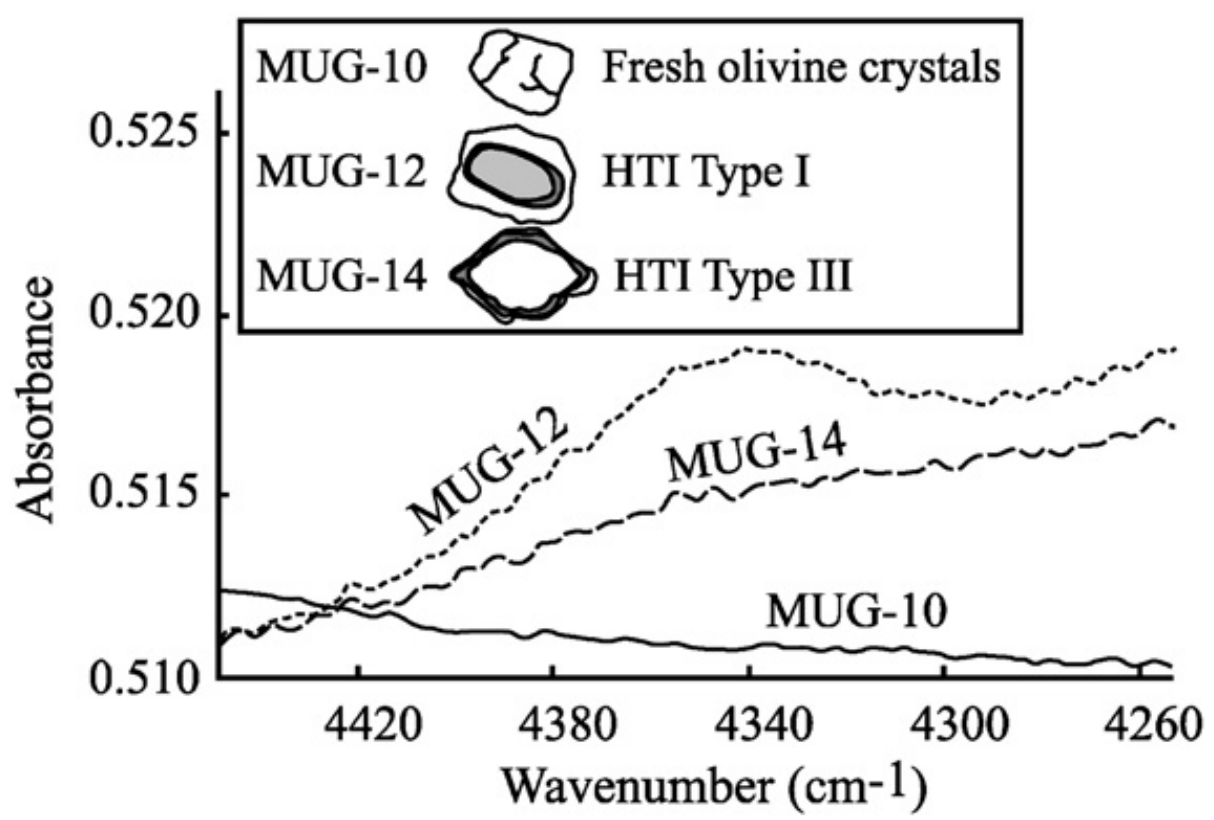

Fig. 9. Diffuse reflectance NIR (Near InfraRed reflectance spectroscopy) spectra in the $4460-4250 \mathrm{~cm}-1$ region of the powders of three separated olivine fractions: 1) fresh olivine crystals (MUG-10); olivines including HTI of type I (MUG-12), and olivines bearing HTI of type III (MUG-14). NIR spectra in the $7200-4000 \mathrm{~cm}-1$ region have been obtained using a Nicolet Maggna 750 FTIR spectrometer with the diffuse reflectance (DRIFT) accessory "Collector" from Spectra-Tech (University of Poitiers, France). The spectrometer is equiped with a $\mathrm{KBr}$ beam splitter and a PbSe detector. The samples have been analysed at room temperature, without dilution in $\mathrm{KBr}$, in a sample cup of about $1 \mathrm{~mm}$-depth and $3 \mathrm{~mm}$ diameter; powders have a random orientation. 


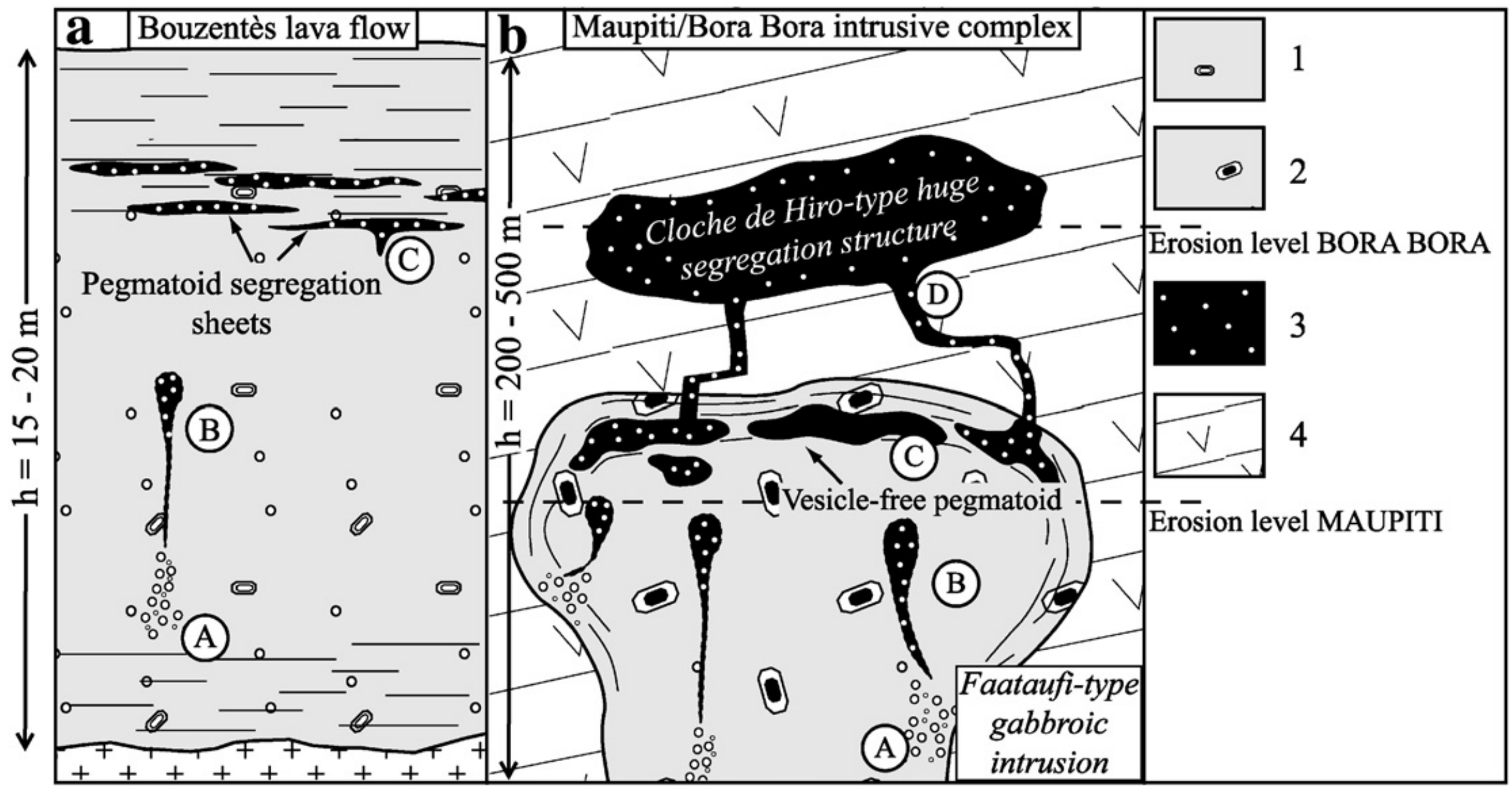

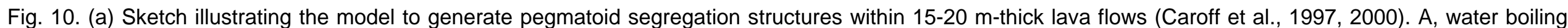

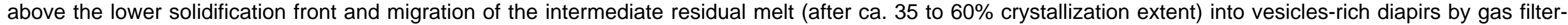

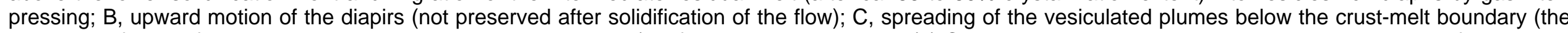

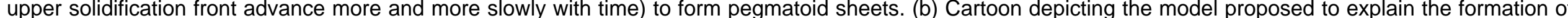

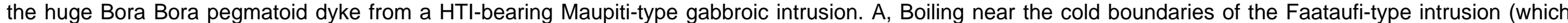

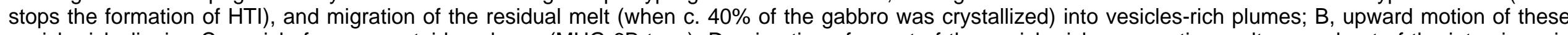

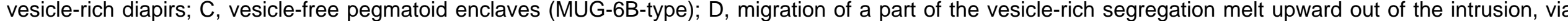

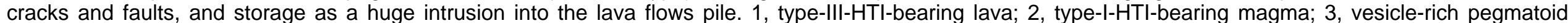
segregation structure; 4 , enclosing lava flows. 